\title{
Kadın Milletvekili Adaylarının Basında Temsili (7 Haziran 2015 ve 1 Kasım 2015 Genel Seçimleri) ${ }^{1}$
}

\author{
Nilay HOȘAF ${ }^{2}$ \\ Erhan ARSLAN ${ }^{3}$
}

\begin{abstract}
öz
Kişinin dünyaya gelmesi ile birlikte başlayan toplumsal cinsiyet öğretileri birçok alanda cinsiyet eşitsizliklerini inşa eden bir durumu ortaya koymaktadır. Bu öğretiler sonucunda kadınlar ikincil konuma itilmekte ve ayrımcılığa uğramaktadır. Dolayısıyla, kadınlar çoğu alandan dışlanmakta ve ait oldukları iddia edilen alanlar ise değersizleştirilmektedir. Siyasal yapı da kadınların dışlandığı alanlardan biridir. Dünün ve bugünün siyasal yapısında kadının temsilini ve bu temsilin basındaki yansımalarını ortaya koyarak tartışmak yarının siyasal temsillerinin daha eşitlikçi olabilmesinin de önünü açmak konusundaki eylemlere bir ivme katabilecektir. Basının siyasal alandaki etkin kullanımından yola çıkılarak kadın milletvekili adaylarının basında yer alan haberlerdeki temsil biçimleri incelenmiştir. Bu doğrultuda, 7 Haziran 2015 ve 1 Kasım 2015 Genel Seçimleri öncesinde milletvekili aday listelerinin açıklandığı tarih itibari ile farklı ideolojilere sahip olan gazetelere (Birgün, Cumhuriyet, Posta, Yeni Akit ve Yeni Şafak) ulaşılmıştır. Bu gazetelerde yer alan haberler; içerik analizi yöntemi ile incelenerek kadın milletvekili adaylarının basında temsil biçiminin toplumsal cinsiyet eşitsizlikleri bağlamında ortaya koyulması amaçlanmıştır. Elde edilen veriler; erkek milletvekili adayları ile ilgili haberlerin kadın milletvekili ile ilgili haberlerden niceliksel olarak gazetelerde daha fazla yer aldığını ortaya koymaktadır. Benzer farklılıklar haberin niteliksel boyutunda da ortaya çıkmaktadır. Bu bağlamda, okur kitlesinin seçim süreçlerinde daha doğru bilgilenebilmesi için basının siyasal alanda kadın adaylar ile ilgili eşitlikçi bir tutum sergilemeleri gerekmektedir.
\end{abstract}

Anahtar Kelimeler: Toplumsal Cinsiyet, Basın, Siyaset, Kadın, Milletvekili Adayları

Alıntı: Hoșaf, N. ve Arslan, E. (2019). Kadın Milletvekili Adaylarının Basında Temsili (7 Haziran 2015 ve 1 Kasım 2015 Genel Seçimleri). Akdeniz Üniversitesi Iletișim Fakültesi Dergisi, (31), sayfa no. 444-470 Doi:

1 Bu çalışma, Mersin Üniversitesi Sosyal Bilimler Enstitüsü Kadın Araştırmaları Ana Bilim Dalı'nda Dr. Öğretim Üyesi Erhan ARSLAN'ın danışmanlığında hazırlanan Nilay Hoşaf'ın aynı isimli yüksek lisans tezinin içerik çözümlemesi ile ilgili bölümünden üretilmiştir.

2 Mersin Üniversitesi Sosyal Bilimler Enstitüsü Kadın Araştırmaları Ana Bilim Dalı, nilayhosaf@gmail.com 3 Dr. Öğretim Üyesi, Mersin Üniversitesi İletişim Fakültesi Gazetecilik Bölümü, erhanarslan@mersin.edu.tr 


\title{
Representation Of Female Parliament Canditates On Media (June 7, 2015 and 1 November 1, 2015 General Elections)
}

\begin{abstract}
Gender doctrines starting with the birth of people has been revealing gender inequality in many areas. With these social doctrines men are prioritized and women are discriminated. For this reason, women are not effective in multiple fields of life and the fields they belong are trivialized. Political structure is among the fields women face discrimination. Discussing and revealing the representation of women and its reflections on media from the past to the present will contribute to the voice of actions made for equality in political representations in the future. On the basis of media's effective use on political area, ways of representation of women parliament candidates on media have been examined. Accordingly, starting with the public announcements of slates before June 7, 2015 and November 1, 2015 General Elections, newspapers with different ideologies (Birgün, Cumhuriyet, Posta, Yeni Akit, and Yeni Şafak) have been reached over. By analyzing these newspapers through content analysis, ways of representation of female parliament candidates on media was aimed to be presented in the context of gender inequality. According to the data obtained, news about men parliament candidates are quantitatively more than the news about women parliament candidates. Similar differences are also present in qualitative comparison. In this regard, media needs to keep a more equitable approach so that masses can have truer information through election process.
\end{abstract}

Keywords: Gender, Media, Politics, Woman, Candidates of Parliament

\section{Giriș}

Toplumların üretim biçimlerinin değişimi toplumsal yapının değişimini beraberinde getirmektedir. Toplumsal hayatın başlangıcından günümüze değin temelde birçok farklılık yaşanmış ve yaşanmaya devam etmektedir. Bu farklıı̆ı̆ yaşanmasında, mihenk taşı diyebileceğimiz, avcı-toplayıcı, göçebe toplumlardan tarımla uğraşan yerleşik toplumlara geçişin önemli bir etkisi vardır.

Üretim biçimlerinin değişimi toplumların yaşayış biçimlerinde farklılıklar yaratmış özellikle cinsiyet rollerinin belirleyici unsuru olmuştur. Üretimde yer alan kadın ve erkeklerin çalışma alanlarında ayrımlar ortaya çıkmış ve cinsiyetler üzerinde toplumsal roller belirlenmiştir. Bu çalışma alanlarının kamusal ve özel alan olarak belirginleşmesi, toplumsal yapıda miras ve mülkiyet sorunlarının baş göstermesi kadınların Engels'in (2012, s.68) deyimiyle büyük tarihsel yenilgilerini yaşamalarına sebep olmuş; cinsiyetçi iş bölümü, ataerki, toplumsal cinsiyet eşitsizlikleri kadınları 'ikinci cins' olarak tanımlamıştır. Kadınlar özel alana hapsedilirken aynı zamanda özel alan değersizleştirilmiştir. Diğer taraftan kamusal alan akılcılıkla işaretlenmiş ve bu alana erkekler egemen olmuştur. 
Kamusal alanın birçok noktasında var olmayan, var olsa da toplumsal cinsiyet eşitsizliğine maruz kalan kadınların siyasette temsil edilmemesi ise toplumsal cinsiyet eşitsizliklerini derinleştirmektedir. Toplumsal cinsiyet eşitsizliklerine başkaldıran kadınlar siyasal alanda var olmak için önemli mücadele alanları oluşturmuşlardır. Dünya'nın her yerinde ses getiren 'kadınlar için oy hakkı' sloganı siyasal yaşama katılım için önemli bir uğrak olmuştur.

Medya tüm dünyada etkin bir biçimde kullanılmakta ve toplumsal yapıda başat roller üstlenmektedir. Siyaset de bu alanlardan biridir. Siyasiler bu araçları aktif kullanarak topluma ulaştırmak istedikleri mesajları etkili bir biçimde aktarırlar. Medya; toplumdaki birçok olay, olgu ve veriyi yeniden inşaa ederek/kurgulayarak hedef kitlesine yansıtmaktadır. Söz konusu bu durum, gelişen yeni iletişim teknolojilerinin sağladığı avantajlar ile medyanın öneminin ve etkisinin daha da artmasını sağlamaktadır. Hiç kuşkusuz ki, bireyin enformasyon intiyacı arttıkça medya içeriklerine olan intiyaç da buna paralel olarak artmaktadır. Özellikle bireyin karar alma süreçlerinde medyayı kullanma ve dolayısıyla içeriklerinden etkilenme durumu üst seviyelere taşınmaktadır. Seçim süreçleri bireyin medyayı en yoğun kullandığı dönemler arasındadır. Gazeteler ise seçim dönemlerinde hem siyasi aktörler hem de seçmenler tarafından sıklıkla tercih edilen bir kitle iletişim aracıdır. Gazete haberlerinde kullanılan dil, seçilen kelimeler, sentaktik yapı, görsel öğeler, haber hiyerarşisi, haberin sunum şekli ve düzenleme biçimi (vb.) içeriği ve söylemin temellerini oluşturmaktadır. Aslında bu noktada karşılıklı etkileşim içerisinde ikili bir durum söz konusudur. Toplumda kullanılan dil medyaya yansırken diğer bir taraftan medya içerikleri toplumda kullanılan dili biçimlendirmektedir. Medyanın kullandığı dil ise toplumsal cinsiyet eşitliğini/eşitsizliğini tesis etmede kritik bir noktada durmaktadır. Birçok alanda ayrımcılığa uğrayan kadınların, siyasal yaşamda hangi rollerle temsil edildiklerinin medyadaki yansımaları açısından ortaya koymak; hem toplumsal cinsiyet eşitliği hem de demokratik mekanizmaların sağlıklı bir biçimde işlemesi açısından önem arz etmektedir. Bu bağlamda çalışmada, kadın milletvekili adaylarının yazılı basında temsil ediliş biçimlerini -haber içerikleri üzerinden- toplumsal cinsiyet eşitliği temelinde incelemek amaçlanmıştır.

Çalışmada yazılı basının kadın milletvekili adaylarını hangi perspektiflerden algıladığını ortaya koymadan önce literatür taraması ile Toplumsal Cinsiyet, Yapısalcı-Iş̧levselci Yaklaşım, Çatışmacı Yaklaşım, Sembolik Etkileşimci Yaklaşım ve Feminist Yaklaşım, Siyasal Katılımda Cinsiyet Eşitliğinin Önemi, Türk Yazılı Basınında Siyasal Alanda Kadının Temsili gibi noktalara değinilmiştir. Çalışmanın uygulamasında ise örneklem grubunu oluşturan 5 gazetenin toplam 200 sayısındaki haberler içerik çözümlemesi ile incelenmiştir. Elde edilen veriler ışığında Türkiye'deki yaygın yazılı basının kadın milletvekillerine ilişkin algısı ortaya koyulmuştur.

\section{Toplumsal Cinsiyet}

Toplumsal cinsiyet (gender), toplumdaki cinsiyet eşitsizliklerine dair kullanılan bir kavramdır. Cinsiyet (sex) kavramı biyolojik cinsiyetler üzerine kurgulanırken, toplumsal cinsiyet kavramı ise sosyo-kültürel ortamın yarattığı cinsiyetler üzerine 
yoğunlaşmaktadır. Benzer yönler taşısa da toplumsal cinsiyet kavramı farklı teorik yaklaşımlar tarafından ele alınmıştır. Ancak yaklaşımların kavranabilmesi için toplumsal cinsiyet kavramının tarihsel ardalanı ile ortaya koyulması gerekmektedir.

Gender kavramı ilk olarak 1972 yılında Annie Oakley tarafından Sex, Gender and Society adlı kitabında kullanılmıştır. Ancak, kavramın yükseldiği dönem 1970' lerin sonları, 1980' lerin başlarıdır (Çardak, 2012, s.7). Çıkışı itibari ile farklı bağlamlarda ele alınmış ve farklı değerlendirmelere tabi tutulmuş bir kavram olan gender, Türkiye'de toplumsal cinsiyet kavramıyla karşılanmaktadır. Başlangıçta toplumsal cinsiyet kavramının seks kavramının sınırlılıklarından, yani cinsler arasındaki farklılıkları yalnız biyolojik temelli olarak tanımlamanın sınırlılıklarından, kurtarmak için kullanıldığı belirtilmektedir (Dedeoğlu, 2000, s.142).

Aaltio-Marjosola ve Kovalainen (2001, s.20) toplumsal cinsiyeti (gender) ilk ve önde gelen toplumsal yapı olarak nitelendirmektedir. Toplumsal yapının değişkenlerinin toplumsal cinsiyet üzerinden şekillendiği görüşüne sahiplerdir. Nicolson (1996:8), toplumsal cinsiyetin cinsiyet (sex) kavramından farklı olduğunu belirtmekte ve toplumsal cinsiyet kavramının cinsiyet üzerindeki toplumsal özellikleri kastettiğini ifade etmektedir. Oakley yine benzer bir tanımlama üzerinden cinsiyetin biyolojik olarak belirlenmiş, toplumsal cinsiyetin ise toplumsal olarak oluşmuş düzlemlere tekabül ettiğini belirtmiştir. Rubin'e göre ise toplumsal cinsiyet kavramı toplumların cinsellik, akrabalık ve üreme ilişkilerini nasıl düzenlendiklerini anlatan bir kavram olarak düşünülmektedir (Akt. Acar Savran, 2004, s. 234).

Joan W. Scott; Toplumsal Cinsiyet: Faydalı Bir Tarihsel Analiz Kategorisi adlı çalışmasında toplumsal cinsiyeti, erkeklerin ve kadınların öznel kimliklerinin sadece toplumsal kökenlerini belirlemenin bir yolu, bedene zorla kabul ettirilmiş bir toplumsal kategori olarak ifade etmektedir (Scott, 2007, s.11). Connell'a göre ise toplumsal cinsiyet insanların eril ve dişil olarak üremeye dayalı bölünmesi kapsamında ya da bu bölünmeyle bağlantılı olarak düzenlenmiş bir pratiktir. Buradan hareketle toplumsal cinsiyet bir nesne olmaktan çok süreçtir ve bu süreç katı bir biçimde toplumsaldır (Connell, 1998, s.190-191). Ayrıca Connell (1998, s.11) yaşanan baskının doğanın değil insan eylemliliğinin bir sonucu olduğuna dikkat çekmiştir. Ecevit (2003, s.83) ise toplumsal cinsiyetin biyolojik cinsiyetten farklı olarak toplumdaki roller, öğrenilmiş davranış ve beklentileri karşılayan bir kavram olarak kullanıldığını vurgulamıştır.

Toplumsal cinsiyet kavramına olan farklı teorik yaklaşımlar ana hatlarıyla dört başlık altında değerlendirilmektedir: Yapısalcı-Işlevselci Yaklaşım, Çatışmacı Yaklaşım, Sembolik Etkileşimci Yaklaşım ve Feminist Yaklaşım.

\subsection{Yapısalcı- İșlevselci Yaklașım}

İşlevselcilik sosyolojide ilk olarak 19. yüzyılda Emile Durkheim tarafından şekillendirilmiştir. Yaklaşımın Amerika'daki öncü ve önemli temsilcisi ise Talcott Parsons olmuştur. Bireylerin sahip olduğu davranışların nedeninin; istekler, maksatlar, yönelimler ve özlemler olduğunu ifade etmektedir (Özalp, 2016, s.26). Toplumu birbiri 
ile bağlantılı parçalardan oluşan bir sistem şeklinde niteleyen yapısalcı- işlevselci yaklaşıma göre bu parçalar biriyle uyum içinde ve dengelidir. Bu parçaların sürekliliğini koruması için ise toplumun intiyaçlarını karşılayan bir role sahip olması gerekir. Burada ailenin toplumun intiyaçlarını karşılan temel bir işlevi olduğu kabul görmektedir. Çünkü aile üreme ve toplumsallaşmayı sağlar. Toplum için çocukları uygun bir biçimde sosyalleştirir. Böylece aile toplum intiyaçlarından bir kısmını karşılamış olur. Ayrıca toplumda var olan iş bölümü de bu yaklaşıma göre gereklidir ve toplumsal gereksinimler üzerine kurgulanmıştır. Yani kadın ve erkeklere yüklenen rollerin gerekli olduğu ileri sürülmektedir. Bu yaklaşım aileyi uyumlu bir toplumsal birim olarak görür ve aile içindeki kadın ve erkeklerin cinsiyet rollerine uygun davranarak birbirini tamamlamasıyla bu uyumun sağlandığını ileri sürerler. Bu noktada feministlerin ailenin uyumlu bir birim olmasına dair karşı çıkışları bulunmaktadır. Çünkü aile içinde ataerkilliği ve eşitsizlikleri barındıran bir yapıya sahiptir ("Toplumsal Cinsiyet sosyolojisi”, 2012).

Robert K. Merton yine kuramın öncü isimlerinde biri olarak Parsons'un yaklaşımını eleştirmiş genel anlamıyla tüm öğelere uyum içindeymişçesine olumlu bir açıdan bakıldığını ama sistemin içinde olumsuz öğeler barındırdığını ileri sürmüştür.

\section{2. Çatıșmacı Yaklașım}

Çatışmacı yaklaşımın ilk ve önde gelen temsilcileri Karl Marx ve Friedrich Engels'tir. Marx ve Engels, yapısalcı- işlevselci yaklaşımın aksini iddia etmişlerdir; toplumu uyumlu ve dengeli bir bütün olarak görmemişler, toplumun çatışmalardan meydana geldiğini ve böylece uygarlığa erişildiğini öne sürmüşlerdir.

Çatışmacı yaklaşıma göre toplum bir bütün olmaktan öte bir süreçtir. Bu süreçte yer alan çatışan ögeler kaçınılmazdır ve ögelerin birbiri ile çatışma halinde olması ise işlevseldir. Toplumsal bütünlük ve ilerleme çatışan ögeler sayesinde gerçekleşir ve bu zıt kuvvetlerin dengelenmesiyle toplumu oluşturur (Özdemir, 2009). Bu çatışan ögeler üretim biçimlerine göre sınıflar altında açıklanmıştır. Yani sınıf ve sınıflar arası çatışma yoksa toplum da yok demektir. Dolayısıyla çatışma içermeyen toplumlarda ilerleme olamayacağı için uygarlıkta ortaya çıkmaz (Yıldııım, 2008, s.443). Sınıfların ortadan kalkmasıyla ise çatışma ortadan kalkacak ve toplum dengeye ulaşacaktır.

Cinsiyetler açısından bu yaklaşımı incelediğimizde ailenin, yapısalcı-işlevselci yaklaşımda olduğu gibi önem teşkil ettiğini görülmektedir. Yine de aile burjuva ailesi ve işçi sınıfı ailesi olarak ayrı ayrı incelenmiş, asıl eleştiri noktası burjuva aileler olmuştur. Toplumun ekonomik olarak incelenmesinin yanı sıra kadınlık ve erkeklikte ekonomik temelli incelenmiştir.

Engels'in (2012) Ailenin, Özel Mülkiyetin ve Devletin Kökeni adlı eserinde üzerinde durduğu konulardan biri anaerkilliktir. Engels cinsiyet eşitsizliklerinin özel mülkiyetin ortaya çıkmasıyla belirginleştiğini öne sürmüştür. Bunu analık hukukunun sona erişi ve 'kadınların tarihsel yenilgisi' olarak nitelendirmiştir. Ayrıca ataerkilliğin ve tek eşliliğinde eklemlendiği bu yapıda ev içi işlerin toplumsallıktan kopması ve 'özel hizmet' haline 
gelmesiyle kadınların toplumdan ayrı bu hizmetleri yerine getirmek zorunda olan bireyler halini aldığını söylemiştir. Kadınlarının kurtuluşu bir taraftan toplumsal üretime katılmakta aranırken diğer yandan ev içi hizmetlerle birlikte sorunlu bir alan teşkil etmektedir. Bu bağlamda Engels evliliklerin 'kadının evsel köleliği üzerine kurulmuş' olduğunu belirterek aile içinde erkeğin burjuva kadının ise proletarya rolünde olduğunu ifade etmiştir.

\subsection{Sembolik Etkileșimci Yaklașım}

Amerikan sosyoloji ekolünde olan sembolik etkileşimci yaklaşımın öncüleri George Herbert Mead ve çalışmalarını kuramsal anlamda derleyip geliştiren öğrencisi Herbert Blumer olarak kabul görmektedir.

Sembolik etkileşimcilik, sosyal eylem ve bireylerin bu eylemlere yükledikleri anlamlar üzerinde duran bir teoridir (Coştu, 2009, s.126). Bireyin toplumda aktör olduğunu ancak yine de toplumsal bağlam olmadan bireyin davranışlarının açıklanamayacağını savunur. 'Yapı, kurum' gibi kavramları kabul etmeyerek 'birlikte eylem' kavramını kullanırlar. Çünkü insanın bir oluş halinde olduğu kabulüyle sosyal düzenin tamamlanmış olarak kurgulanması olanaklı değildir (Güngör, 2013, s.67). Bireylerin toplumla semboller aracılığıyla iletişim kurduğu belirtilmektedir. Yani sosyal etkileşim için sembolik araçlar kullanılmaktadır ve bunlardan en geniş ve etkili olanı dildir. Dil ve jestler sayesinde sembolik etkileşim gerçekleştirilir. Bu yaklaşım bireyin davranışlarının bulunduğu toplumsal grubun davranışı olduğunu ve etkileşimin önemini vurgulamaktadırlar (Sankır, 2010, s.2-6). Burada etkileşim sadece bir tepki süreci olarak kurgulanmaz etkileşim sembollerin anlamlandırılması sürecini kapsamaktadır.

Etkileşime yapılan vurgu bireyler arasında olduğu gibi cinsler arasında da önemini korumaktadır. Sosyal ortamın değerlendirmesinde kullanılan araçsal sembollerin eril ya da dişil özellikte olması bu araçları kullananları etkilemekte ve bireylerin sosyal dünyayı anlamlandırılışı buna göre belirlenmektedir (Sankır, 2010, s.11). Bu doğrultuda toplumsal cinsiyet rolleri etkileşimci bir alanda tanımlanmakta, aile ise etkileşim halindeki bireylerin birliği olarak açıklanmaktadır. Bireyler aile içindeki rol ve beklentileri algılayarak kendine göre belirli rolleri olan bir konum edinmektedir (Özdemir, 2009). Aile kurumu yerine 'aile birlikteliği' kavramını kullanarak ailenin diğer 'birliktelikler' gibi durağan olmadığı vurgulanmaktadır (Güngör, 2013, s.67-68). Toplumsal cinsiyet rollerinin sembolik etkileşimci yaklaşım tarafından ele alınması kadınlık ve erkeklik rollerinin de semboller aracılığıyla aktarılıyor olması ile bağlantılıdır. Toplumsal etkileşim içerisindeki sembollerin eril ve dişil karakterler taşıyarak erkek tahakkümünü pekiştiren bir yapıya sahip olduğunu böylece kadınların ikincil konuma toplumsal etkileşimdeki araçlarla itildiği belirtilmektedir. Sembolik etkileşimci yaklaşım toplumsal yapıya gerektiği kadar yer vermemesi gerekçesiyle eleştirilmiştir. 


\subsection{Feminist Yaklașım}

Ataerkil toplumsal yapı içerisinde cinsiyetler üzerinden gerçekleştirilen kutuplaştırmalar kadınları değersizleştirmektedir. Buradan yola çıkan eleştirel bir yaklaşım olarak feminist yaklaşım kadınlara uygulanan bu evrensel ayrımcılığın karşısında her alanda mücadelenin ana hattını oluşturmaktadır.

Feminizm 17. yüzyıla kadar dayandırılabilmekle birlikte yaşam hakkını savunarak kısıtlama ve ayrımcılık üzerinden yola çıkmıştır (Özlük, 2007, s.199). 18. yüzyıl ile birlikte ise değişen dünyadaki gelişmeler feminist harekete büyük bir ivme kazandırmış ve kadınlar için önemli gelişmeler yaşanmıştır. Olympe de Gouges 1791'de Fransız Devrimi'nin erken dönemlerinde Les Droits de la Femme (Kadın Hakları) adlı bir el broşürü yayınlamıştır. 1792 yılında tarihteki ilk önemli feminist çalışma olan A Vindication of the Rights of Woman (Kadın Haklarının Savunusu) adlı eser Mary Wollstonecraft tarafından kaleme alınmıştır ve bu sonraki feminist düşünce için başat eser olmuştur (Donovan, 2014, s.21). Ayrıca bu eser ilk modern feminizm metnidir (Aktaş, 2013, s.60). Aydınlanma düşüncesinin etkisinin belirgin olduğu bu dönemde kadınlar kamusal alanda erkeklerle eşit haklara sahip olmayı talep etmişlerdir. Özellikle kadınlara oy hakkı için mücadele edilmiş ve oy hakkının alınmasıyla birlikte bunun yeterli olmayacağı anlaşılmıştır. Yeni mücadele alanları böylelikle feminist hareket içinde yer edinmiştir. Kadınların oy hakkı talebiyle gelişen feminist kuram, özel/kamusal alan ayrımlarını bozan ve kadınlık durumlarını farklı kimliklerle bütünleştiren bir iktidar eleştirisine dönüşmüştür (Aslan ve Gambetti, 2009, s.6).

Feminizm bütün kadınları bütünsel bir ezilmişlikte birleştirir; yani her kadını kapsamaktadır (Mitchell, 2006, s.20). Ancak dünyada yaşanan gelişmeler feminizm kuramını etkileyerek dönemsel farklar ve ayrılıkları ortaya çıkarmıştır. Feminist kuram ve hareket tüm kadınları kapsıyor olsa da tek bir feminizmden söz etmek mümkün görünmemektedir. Feminizmin tarihsel süreci, 19. yüzyıldan 21. yüzyıla kadarki dönemi kapsamakta ve üç dalgaya ayrılmaktadır. Donovan, birinci dalga olarak kabul edilen dönemden önce de feminizmin var olduğunu ancak toplumda belirgin ve güçlü olduğu dönemin birinci dalga olarak nitelendirildiğini ve feminist tarihin dalgalar halinde incelenmesinde uzlaşıldığını belirtmiştir (2014, s.15). Bu feminist dalgalarda kadınlar, evrensel ve bireysel olarak meşru haklarını elde etmek için mücadele etmişlerdir (Taş, 2016, s.163).

\section{Siyasal Katılımda Cinsiyet Eșitliğinin Önemi}

Cinsiyet eşitsizliği ile işaretlenen temel alanlardan biri siyasettir. Dünya nüfusunun yarısını oluşturan kadınların siyasal alana katılımı ve temsiliyeti genel anlamda oldukça düşüktür. Inter-Parliamentary Union -IPU- (Parlamentolar Birliği) 2017 verilerine göre dünya genelinde parlamentolarda kadın oranı yalnızca yüzde 23,4'tür. Siyasette ve yönetimde kadınların varlığı, kadınlara karşı uygulanan cinsiyet ayrımcılıklarının önüne geçmek ve eşitliği sağlamak için gerekli yasal süreçleri başlatmayı ve kadınların siyasal ve ekonomik alanlara tam katılımını sağlayacak özel önlemler almayı olanaklı 
kılmaktadır (Gül, 2007, s.15). Ancak siyasal katılım yalnız ayrımcılığı önlemek ve eşitlik arayışının bir ürünü değildir. Kadınların siyasal katılımı eşitlik ve adalet için büyük önem taşımaktadır. Fakat bunun yanı sıra siyasal katılım konusu, birlikte siyasal alanda var olabilmek bağlamında kurgulanmaktadır. Yani zaten eril alan olarak atfedilen siyasete kadınları da katmak değil eşit ölçüde temsiliyeti vurgulamak değerlidir. İktidarın; bireylerin yaşamı, toplumun, ülkenin geleceği için vereceği kararların meşru olabilmesi için, bu kararlardan etkilenenlerce seçilmesi ve onların tercihlerini yansıtması temel ilkedir. Bu ise herkesin seçme hakkına sahip olmasını ve siyasi karar organlarında toplumun dengeli temsil edilmesini gerektirir (Gökçimen, 2008, s.31). Ancak böylelikle tüm kararlar meşru kabul edilebilir. Parlamento ve yerel yönetimlerde dengeli temsil edilebilme açısından sayıların ve oranların yanı sıra önemli noktalardan biri niteliktir. Temsil edecek kişi ve kişilerin kadın bakış açısı bağlamında değerlere sahip olması önemlidir. Ayrıca kadınların siyasal alandaki temsili pratik ve pragmatik bir açıdan değerlendirildiğinde kadınların siyasal alandaki temsilinin ekonomik ve toplumsal alanda gözlemlenen dengesizliklerin giderilmesinde anahtar rol olabileceği kabul edilebilmektedir (Esen ve Memişoğlu, 2007, s.7). Kadınların toplumda ayrımcılığa uğrayan, ikincil olarak konumlandırılan, baskılara ve dışlanmaya maruz kalan durumlarını aşabilmeleri; önemli ölçüde siyasette erkekler ile eşit oranda söz sahibi olabilmelerine bağııdır.

\subsection{Türk Yazılı Basınında Siyasal Alanda Kadının Temsili}

Medya aracılığı ile her gün sayısız kez kadınlık ve erkeklik rolleri topluma aktarılmaktadır. Kadına ve erkeğe atfedilen roller sürekli bir biçimde vurgulanmakta, doğrunun ve olması gerekenin bu olduğu kanıksatılmaya çalışılmaktadır. Kadınlık ve erkeklik kurgusu hem toplumsal cinsiyet eşitsizliklerinden beslenerek yansıtılmakta hem de yaratılmaktadır. Pekiştirilen bu roller her alanda ikincil konuma itilen cinsiyet olan kadınlar için daha ağırdır. Kadınlar, medyada -istisnalar dışında- ya cinsellikleri ile ya da özel alanla sınırlandırılarak sunulmaktadır.

Günümüzde medya erişim alanı ve özellikle anlık bilgi aktarımı sağlaması açısından büyük bir öneme sahiptir. Medya kullandığı sözel ve görsel dil aracılığıyla toplumun büyük bir bölümünü etkin bir biçimde etkilemekte ve yönlendirmektedir. Medya, eşit olmayan toplumdaki güç ilişkilerini yansıtan, bu ilişkileri yeniden üreten, toplumdaki ekonomik, siyasal ve sosyal dinamikler tarafından şekillendirilen aynı zamanda tüm bu dinamikleri şekillendirme ve dönüştürme gücüne sahip bir kurum olarak işlev görmektedir (Kaylı, 2014, s. 6340-6341). Özellikle günümüzde evrensel bir biçimde hızlanan iletişim ağı göz önüne alındığında medyanın toplum üzerindeki etkisi büyük bir öneme sahip olacaktır.

Eğlendirme, bilgilendirme, kültürel şekillenme, siyasileşme ve toplumsallaşma rollerine sahip olan medya, kültür üretiminin dağıtımının belirleyicisi olarak ortaya çıkmışıı (Fidan, 2000, s.123). Türkiye'de egemen olan ekonomik, siyasal ve sosyal dinamikler ülkedeki medyanın biçimlenmesinde etkin rol oynamıştır. Eşitlikten yana, tarafsız ve egemen güçlerin etkisi altında olmaması üzerinden kurguladığımız medya tahayyülü 
maalesef tam tersi bir biçimde şekillenmiştir. Cinsiyetçilik, farklı cinslerin medyada hatalı temsilinden ücret eşitsizliğine kadar pek çok alanda kendisini gösterebilmektedir (Arsan, Ünalan ve Türkoğlu, 2009, s.386) Medyanın - istisnalar dışında- her alanına etki eden gücün ve güçlünün hegemonyası, cinsiyet eşitliği kapsamında da belirgin bir etkiye sahiptir. Toplumda kabul edilen egemen gücün erkek olması nedeniyle erkek egemen bir medya yaratılmakta ve bu durum medyanın topluma erkek egemen iletiler vermesiyle birbirini doğuran bir halde sürdürülmektedir. Değerlerin üretiminde ve kadınerkek rollerinin yaratımı sürecinde medya içeriklerinin etkisi vardır (O'Shaughnessy ve Stadler, 2012). Cinsiyetçi ifadeler toplumda olduğu gibi medyada da sıklıkla yer almakta, kadına ve erkeğe toplum tarafından biçilen toplumsal cinsiyet rolleri medyanın yansıttığı kadın ve erkek rolleriyle örtüşmektedir. Böylece medya toplumsal cinsiyet eşitsizliklerinin yeniden üretilmesine, pekiştirilmesine ve sürdürülmesine neden olmaktadır. Saktanber (1993, s.202), kadınların medyada ele alınış biçimlerinin kadının toplumda tanımlanmış haliyle doğrudan ilişkili olduğunu vurgulamaktadır.

Kadınlar medyada özellikle tüketim nesnesi olarak araçsallaştırılmaktadır. Kadın, medya aracılığı ile tüketime yönlendirilmekte, kapitalist pazar ortamına, tüketen ve tüketilen olarak katılmaları sağlanmaktadır (Özdamar, 2009, s.117). Kadınların bedenini meta haline getirerek bu dev pazarda yer edinmeye çalışan, kâr amacı güden ve reyting kaygısı taşıyan medya grupları fazlasıyla mevcuttur. Medya, her gün kullandığı cinsiyet ayrımcılığını pekiştiren ifadeler, yorumlar, görüntüler, alıntılar ile kadın bedeni üzerinden cinsiyetçi bir söylem inşa etmektedir (Köse, 2011, s.408). Meta olarak kullanılan kadın bedenleri ile ideal olanın algısı yaratılmakta ve topluma kazandırılmaktadır. Reklamlarda tanıtılan ürünün ilgi çekmesi adına erotik görsellere yer verilmekte, gazeteleri “arka sayfa güzelleri” süslemektedir. Böylelikle medya grupları büyük bir rekabete dönüşen bu alanda yer almaya ve yükselmeye çalışmaktadır. Bunun yanı sıra toplumsal cinsiyet eşitsizlikleri tekrar ve tekrar üretilmekte ve en yaygın kanal olan medya aracılığıyla toplum tarafından kanıksanması sağlanmaktadır. Cinsellik dışında medyada konumlandırılan kadınlar ise "fedakâr anne, iyi eş, hamarat gelin..." gibi yine özel alana dair olan ve kadınlık üzerinden kurgulanan rolleri yansıtır niteliktedir. Dolayısıyla kadınlar medyanın çeşitli alanlarında kendi seyredilişlerini seyrederlerken, bir yandan da onlardan talep edilen ideal kadının ne olduğu gösterilir ve onlara "kendini benim seni sevdiğim gibi sev, benim istediğim gibi ol" denir (Saktanber, 1993, s.189).

\section{Yöntem}

\subsection{Araștırmanın Problemi}

Medya toplumdaki birçok unsurun yansıtıldığı ve yeniden inşa edildiği bir alan olarak özellikle günümüzde önemini korumaktadır. Medyada kullanılan dil ve görsel öğeler ise oluşturulacak sunumun içeriğini teşkil etmektedir. Toplumda kullanılan dil medyaya yansırken diğer bir taraftan medya da toplumda kullanılan dili biçimlendirebilmektedir. Görsel öğelerle oluşturulan sunum, olumlu veya olumsuz bir biçimde kişileri etkilemektedir. Bu noktada, evrensel bir biçimde ayrımcılığa uğrayan kadınlar için toplumda başat bir rol oynayan medyanın önemi büyüktür. Bu nedenle kadınların toplumdaki var olan durumunu değiştirebilecek etkenlerden biri olan medyada 
kadınların sunum biçimlerinin incelenmesi gerekmektedir. Toplumdaki cinsiyetçi iş bölümünün her alana yansıdığı gibi medyada da yer aldığı görülmektedir. Eşitliğe sahip olunamayan alanların başında gelen siyaset ise Dünya'da ve Türkiye'de eril bir hegemonya altındadır. Medya siyasetin ve siyasilerin kullandığı etkin bir araç olarak işlev görürken; siyasette yer alan kadınları ele alış biçimlerinin toplumsal cinsiyet eşitsizlikleri barındırıp barındırmamasının sorgulanması değerlidir. Bu çalışmada ise yazılı basın incelemesi üzerinde durulmuştur. Çalışmanın temel sorunsalı; yaygın yazılı basında kadın milletvekili adaylarının haberlerdeki yer alış biçimlerini ve cinsiyet eşitsizliklerini ortaya koyabilmektir.

\subsection{Araștırmanın Amacı ve Kapsamı}

Günümüzde medyanın insanlar üzerinde büyük bir etkiye sahip olduğu görülmektedir. Medya, bilgilendirmek ile birlikte yönlendirici bir etkiye de sahip olmasıyla toplumsal cinsiyet öğelerini biçimlendirebilmekte ve yeniden üretebilmektedir. Medyanın toplumsal yaşamdaki rolünü dikkate aldığımızda ise dil ve görsel öğelerin sunuş biçimlerini anlamlandırmak gerekliliği doğmaktadır. Bu bağlamda çalışmada kadın milletvekili adaylarının yazılı basında temsil ediliş biçimlerini toplumsal cinsiyet eşitsizlikleri temelinde, feminist bir bakış açısı ile incelemek amaçlanmıştır. Çalışmada kadının basında temsilinin toplumsal cinsiyet eşitsizlikleri bağlamında feminist bakış açısıyla incelenmesi; toplumun büyük bir bölümünü etkileyen basının cinsiyetçi bir tutum geliştirip geliştirmediğinin sorgulanması ve olası bir cinsiyetçi yönelime karşı önerilerin ortaya konulması açısından önem taşımaktadır.

\subsection{Sayiltılar}

Çalışmada siyasal alandaki toplumsal cinsiyet eşitsizlikleri sorgulanarak Dünya ve Türkiye tarihinde kadınların siyasal alanda eşitlik için verdikleri mücadelelere değinilmiştir. Medyanın toplumsal cinsiyet eşitliğinde durduğu yer genel hatları ile çizilerek, siyasete etkisi incelenmiş ve yine Türkiye tarihi açısından kadınların siyasal eşitlik mücadelesinde medyayı, özellikle yazılı basını kullanım biçimlerinin tarihsel bir çerçevesi çizilmiştir. Ardından 7 Haziran 2015 ve 1 Kasım 2015 Genel seçimlerinde kadınların yazılı basında temsilini incelemek üzere içerik analizi gerçekleştirilmiştir. Bu noktada sayıltılar şu şekildedir;

- Erkek milletvekili adayı ile ilgili haberler kadın milletvekili adayı ile ilgili yapılan haberlere göre daha çok birinci sayfada yer almaktadır.

- Kadın milletvekili adayı ile ilgili haberlerin sayfadaki konumu erkek milletvekili ile ilgili haberlere göre daha az dikkat çeken bir konuma sahiptir.

- Kadın milletvekili adayı ile ilgili haberler daha çok iç sayfalarda yer almaktadır.

- Kadın milletvekili adayı ile ilgili haberlerde çoğunlukla farklı aktörler devreye girmektedir.

- Kadın milletvekili adayları daha çok magazinel söylemlerle ele alınmıştır.

- Farkıı ideolojilere sahip yazılı basında yer alan kadın milletvekili adayları ile ilgili haberlerin adaya bakış açısında büyük farklılıklar yoktur. 


\subsection{Araștırma Metodolojisi}

Çalışmada verilere ulaşabilmek amacıyla içerik analizi gerçekleştirilmiştir. Sistematik bir inceleme gerektiren içerik analizi ile haberlerin hiyerarşik konum ve sıralamasına, haberlerin düzenleme biçimine, görsel materyallerin kullanımına, haberdeki aktörlere, haberin kaynaklarına ve temel konularına dair bulgular elde edilebilmektedir. Ayrıca bu bulgular benzer veya farklılıklarına göre sınıflandırılarak okuyucu için anlamlı bir bütün halinde sunulabilmektedir.

\section{5. Örneklem}

Araştırmada farklı ideolojilere ve mülkiyet yapılarına sahip olan 5 gazete seçilmiştir: Birgün, Cumhuriyet, Posta, Yeni Şafak ve Yeni Akit. Örneklemi oluşturan gazetelerin seçiminde gazetelerin ideolojik yörüngeleri baz alınmıştır. Merkezden Posta, ortanın solundan Cumhuriyet, ortanın sağından Yeni Şafak, radikal soldan Birgün ve radikal sağdan ise Yeni Akit gazetesi seçilmiş; böylelikle her ideolojinin temsilinin sağlanması amaçlanmıştır.

Çalışmanın zaman aralığını ise 7 Haziran 2015 ve 1 Kasım 2015 Genel Seçimleri, oluşturmaktadır. Araştırmada 7 Haziran 2015 Genel Seçimi için milletvekili aday listelerinin açıklanmasını takip eden on gün (8 Nisan 2015 - 17 Nisan 2015) boyunca yayınlanan onar günlük gazete ve seçim yasaklarından on gün öncesini kapsayan tarihte (27 Mayıs 2015-5 Haziran 2015) yayınlanan onar günlük gazete olmak üzere, yine 1 Kasım 2015 Genel Seçimi için aday listelerinin açıklanmasının ardından 19 Eylül 2015- 28 Ekim 2015 tarihleri arasında ve 13 Ekim 2015- 22 Ekim 2015 tarihleri arasında yayınlanan onar günlük 5 gazete incelenmiştir. Bu doğrultuda; her iki seçim döneminden, örneklemi oluşturan gazetelerden toplam 40 gün boyunca basılan 200 gazete; içerik analizi ile incelenmiştir.

\subsection{Sinırlılıklar}

Bu çalışmada milletvekili adayı dışındaki kadın odaklı diğer haberler kapsama dâhil edilmemiştir. İçerik analizinde kadın ve erkek milletvekili adayları ile ilgili olan haberlerin hiyerarşik yapısı incelenmiştir. İçerik analizinin diğer kriterleri yalnız kadın milletvekili adayları ile ilgili olan haberler üzerinde gerçekleştirilerek sınırlandırılmıştır.

\subsection{Alanyazın}

Habercilik bağlamında IPS İletişim Vakfı tarafından çıkarılan Sevda Alankuş' un derlediği Kadın Odaklı Habercilik kitabı daha eşitlikçi bir habercilik adına Türkiye'deki haberciliğe bir alternatif yaratmayı amaçlamaktadır.

Huriye Kuruoğlu ve Bermal Aydın'ın editörlüğünü yaptığı Toplumsal Cinsiyet ve Medya adlı kitapta kalıplaşmış toplumsal cinsiyet yargılarının ters yüz edilmesinin bu yargıları 
teşhir etmekten geçtiği ifade edilmiştir. Bu bağlamda kitle iletişim araçlarında erkek egemen bakış açısıyla üretilen ve pekiştirilen toplumsal cinsiyet rol tanımları ve söylemleri teşhir edilmiştir.

Şahinde Yavuz tarafından derlenen Toplumsal Cinsiyet ve Medya Temsilleri adlı kitapta medyanın kurguladığı dünyada erkeklerin kadınların ve LGBTi bireylerin nasıl temsil edilmekte olduğu sorusu ile yola çıkılmıştır. Rekabetin hızla yayıldığı ve vahşileştiği medya ortamında var olan temsillerin çarpıklığını, statükoyu nasıl beslediğini ya da bazılarını yok saydığını göstermek amaçlanmıştır.

Hicran Özdamar'ın 2009 yılında hazırladığı Lâik-Antilâik Ekseninde Kadının Siyasallaşmasının Türk Yazılı Basınındaki Temsili adlı yüksek lisans tezi kapsamlı bir çalışmayı ortaya koymuştur. 8 Mart Dünya Emekçi Kadınlar Günü'ne dair yapılan haberler Teun Van Dijk'in söylem analizi yöntemi kullanılarak incelenmiştir. 7 Mart 2007, 8 Mart 2007 ve 9 Mart 2007 tarihlerinde yayınlanan Vakit, Birgün, Cumhuriyet, Evrensel, Hürriyet, Milliyet, Milli Gazete, Radikal, Sabah, Yeni Şafak, Yeniçağ, Zaman gazeteleri ele alınmıştır.

Medyanın kadınlar üzerindeki etkisini belirlemek amacıyla Nurcan Koparan' ın 2007 yılında hazırladığı Medyanın Kadınlar Üzerine Etkileri adlı yüksek lisans tezinde Çorum ilinin merkez ilçesinde ikamet eden sosyo-ekonomik düzeyleri farklı 500 kadın üzerinde araştırma gerçekleştirilmiştir. Veri toplama aracı olarak anket formu kullanılmıştır.

2010 yılında Hülya İncekul tarafından hazırlanan Kadın Kimliğinin Algılanmasında Medyanın Rolü adlı yüksek lisans tezi ile en çok okunan farklı ideolojilere sahip 3 kadın köşe yazarın, Hürriyet gazetesinden Ayşe Arman, Radikal gazetesinden Perihan Mağden ve Zaman gazetesinden Nihal Bengisu Karaca vasıtasıyla hangi toplumsal cinsiyet mesajları satır arasına gizlenmektedir, bunun söylem analizi yöntemi ile incelenmesi ve bu vasıtayla medya da kadın kimliği nasıl yansıtılmakta olduğunun ortaya konulmasını içermektedir. Aynı zamanda bu yazarların medya aracılığıyla cinsiyetçi bir yaklaşım belirleyip belirlemediğinin araştırımasını amaçlamaktadır.

Derya Şaşman Kaylı' nın Türkiye'de Yazılı Basında Parlementodaki Siyasi Partilerin Kadın Politikalarının Temsili: 2011 Genel Seçimleri Üzerine Bir Inceleme başlıkıı makalesinde; 2011 genel seçimleri öncesi 1 Nisan 2011-30 Haziran 2011 tarihlerini kapsayan 91 günlük dönemde, Cumhuriyet, Zaman, Birgün ve Hürriyet gazeteleri örneğinde, parlamentoda yer alan partilerin, yazılı basında yer alan kadın politikaları incelenmiştir. İncelemede Ten Van Dijk' in söylem analizi yöntemi kullanılmıştır.

Şaziye Deniz'in Yurttaşlık Ideali Perspektifinden Ingiliz Yazılı Basınında Kadın -Siyaset İlişkisinin Temsili başııkı makalesinde; kadın-politika ilişkisinin İngiltere yazılı basınında nasıl temsil edildiğini ortaya çıkarmayı amaçlamıştır. Ingiltere’nin önde gelen gazeteleri olan The Daily Telegraph, The Guardian'da, son genel seçim döneminde kadın-siyaset ilişkisinin temsil biçimleri, söylem analizi yöntemi ile ele alınmıştır. 01 Nisan 2010 ile 31 Mayıs 2010 tarihleri arasında 61 günlük bir süreç incelenmiştir. 


\section{Bulgular ve Tartıșma}

İçerik analizi ile incelenen gazetelerde nicel verilerin anlamlı bir biçimde ortaya konulması amaçlanmaktadır. Kadın ve erkek milletvekili adayları ile ilgili haberler belirli çerçevelerde oluşturulan sorular ile incelenmiştir. Oluşturulan kodlama forumları ile içerik analizi incelemesi gazetelere uygulanarak aşağıdaki verilere ulaşılmıştır. SPSS 20 programı kullanılarak veriler işlenmiş, tablo biçiminde sunulmuş ve yorumlanmıştır.

\subsection{Kadın Milletvekili Adayları İle İlgili Haberlerin İçerik Çözümlemesi}

Tablo 1. Gazetelere göre kadın milletvekili adayları ile ilgili haber dağılımları

\begin{tabular}{|l|c|c|}
\hline Gazete İsimleri & $\mathbf{f}$ & $\%$ \\
\hline Birgün & 22 & 15,2 \\
\hline Cumhuriyet & 38 & 26,2 \\
\hline Posta & 25 & 17,2 \\
\hline Yeni Şafak & 27 & 18,6 \\
\hline Yeni Akit & 33 & 22,8 \\
\hline Toplam & $\mathbf{1 4 5}$ & $\mathbf{1 0 0 , 0}$ \\
\hline
\end{tabular}

Seçim süreçlerinde örneklem çerçevesinde incelenen gazetelerin kadın milletvekili adayları ile ilgili haber dağılımları tablo 1.'de yer almaktadır. Elde edilen verilere göre 200 günlük gazete incelemesinde toplam 145 haber kadın milletvekili adayları ${ }^{4}$ ile ilgilidir. İncelenen gazetelerden belirlenen sınırlılıklar dâhilinde en çok haberi 38 haber ile Cumhuriyet gazetesi yayınlamıştır. Yeni Akit 33, Yeni Şafak 27, Posta 25, ve Birgün gazetesi ise 22 haber yayınlamıştır. Cumhuriyet gazetesi kadın adaylarla ilgili haberlere daha çok yer vererek seçim sürecinde diğer gazetelere göre kadın adayları daha çok gündeme getirmiştir.

Tablo 2. Gazetelere göre kadın milletvekili adayları ile ilgili haberlerin yer aldığı sayfalar

\begin{tabular}{|c|c|c|c|c|c|c|c|c|c|c|c|c|}
\hline \multirow{3}{*}{$\begin{array}{l}\text { Haberin } \\
\text { Sayfası }\end{array}$} & \multicolumn{10}{|c|}{ Gazeteler } & \multirow{2}{*}{\multicolumn{2}{|c|}{ Toplam }} \\
\hline & \multicolumn{2}{|c|}{ Birgün } & \multicolumn{2}{|c|}{ Cumhuriyet } & \multicolumn{2}{|c|}{ Posta } & \multicolumn{2}{|c|}{ Yeni Şafak } & \multicolumn{2}{|c|}{ Yeni Akit } & & \\
\hline & $f$ & $\%$ & $f$ & $\%$ & $f$ & $\%$ & $f$ & $\%$ & $f$ & $\%$ & $f$ & $\%$ \\
\hline $\begin{array}{l}\text { Birinci } \\
\text { Sayfa }\end{array}$ & 0 & 0 & 1 & 2,6 & 3 & 12,0 & 3 & 11,1 & 0 & 0 & 7 & 4,8 \\
\hline İç Sayfa & 14 & 63,6 & 28 & 73,7 & 18 & 72,0 & 20 & 74,1 & 25 & 75,8 & 105 & 72,4 \\
\hline
\end{tabular}

4 İçerik analizinin kodlama aşamasında sadece kadın milletvekili adaylarının yer aldığı haberlerin yanı sıra; erkek ve kadın milletvekili adaylarının aynı haberde konu edildiği gazete içerikleri de değerlendirmeye alınmıştır. 


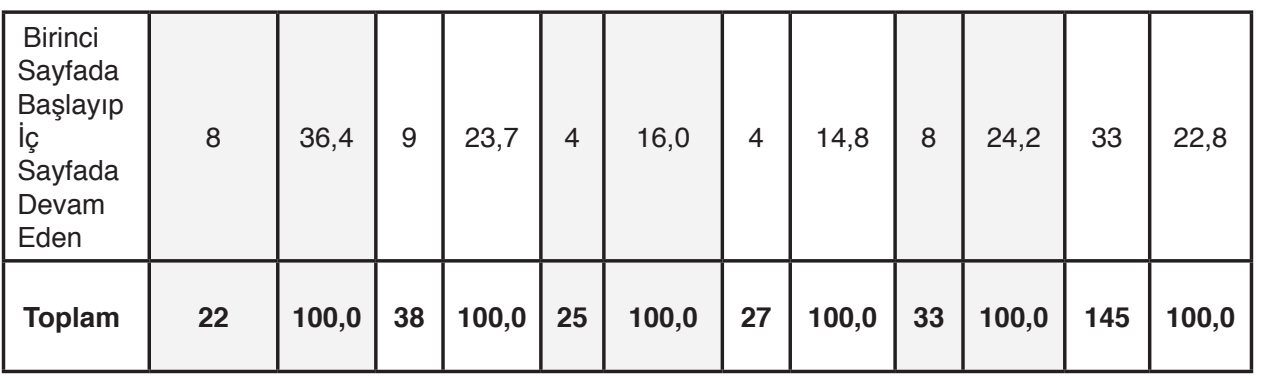

Elde edilen verilere göre kadın milletvekili adayları ile ilgili haberlere birinci sayfada ve birinci sayfada başlayıp iç sayfada devam eden haberler şeklinde en çok yer veren gazete Cumhuriyet gazetesidir. Ancak kendi haber sayısı içerisinde haberlere birinci sayfada en çok yer veren gazete $\% 36,4$ oranı ile Birgün gazetesidir. En çok haberin yer aldığı gazete Cumhuriyet gazetesi olmasına rağmen bu gazetede haberlerin \%73,7'lik oranı iç sayfalarda yer almıştır. Kadın adaylar ile ilgili haberlere sadece birinci sayfada en çok yer veren gazeteler ise Posta ve Yeni Şafak gazeteleri olmuştur. Gazetelerde kadın milletvekili adayları ile ilgili haberlerin büyük bölümü $(\% 72,4)$ iç sayfalarda yer almıştır. İncelenen gazetelerde kadın adaylar ile ilgili haberlere iç sayfalarda yer verme oranları birbirine çok yakındır. Bu noktada gazetelerin benzer tutumlar geliştirdiği görülmektedir.

Tablo 3. Gazetelere göre kadın milletvekili adayları ile ilgili haberlerin sayfadaki konumu

\begin{tabular}{|c|c|c|c|c|c|c|c|c|c|c|c|c|}
\hline \multirow{3}{*}{$\begin{array}{l}\text { Haberin } \\
\text { Sayfadaki } \\
\text { Konumu }\end{array}$} & \multicolumn{10}{|c|}{ Gazeteler } & & \\
\hline & \multicolumn{2}{|c|}{ Birgün } & \multicolumn{2}{|c|}{ Cumhuriyet } & \multicolumn{2}{|c|}{ Posta } & \multicolumn{2}{|c|}{ Yeni Şafak } & \multicolumn{2}{|c|}{ Yeni Akit } & \multicolumn{2}{|c|}{ Toplam } \\
\hline & $f$ & $\%$ & $f$ & $\%$ & $f$ & $\%$ & $f$ & $\%$ & $f$ & $\%$ & $f$ & $\%$ \\
\hline Sürmanşet & 3 & 13,6 & 0 & 0 & 0 & 0 & 1 & 3,7 & 2 & 6,1 & 6 & 4,1 \\
\hline Manşet & 1 & 4,5 & 0 & 0 & 5 & 20,0 & 2 & 7,4 & 4 & 12,1 & 12 & 8,3 \\
\hline Üst Kuşak & 4 & 18,2 & 7 & 18,4 & 6 & 24,0 & 7 & 25,9 & 5 & 15,2 & 29 & 20,0 \\
\hline Göbek & 5 & 22,7 & 19 & 50,0 & 10 & 40,0 & 9 & 33,3 & 9 & 27,3 & 52 & 35,9 \\
\hline Alt Kuşak & 9 & 40,9 & 12 & 31,6 & 4 & 16,0 & 7 & 25,9 & 11 & 33,3 & 43 & 29,7 \\
\hline Tam Sayfa & 0 & 0 & 0 & 0 & 0 & 0 & 1 & 3,7 & 2 & 6,1 & 3 & 2,1 \\
\hline Toplam & 22 & 100,0 & 38 & 100,0 & 25 & 100,0 & 27 & 100,0 & 33 & 100,0 & 145 & 100,0 \\
\hline
\end{tabular}

Kadın adaylar ile ilgili haberlere sürmanşette en fazla yer veren gazete 3 haber $(\% 13,6)$ ile Birgün gazetesi olmuştur. Manşeti en fazla kullanan gazete ise 5 haber ile Posta gazetesidir. Tam sayfa haberlere yalnız 3 kere yer verilmiş olup bunlardan 
2'si Yeni Akit, 1'i ise Yeni Şafak gazetesinde yer almıştır. Gazetelerde kadın adaylar ile ilgili yayınlanan haberler çoğunlukla; Birgün gazetesinde alt kuşakta, Cumhuriyet gazetesinde göbekte, Posta gazetesinde göbekte, Yeni Şafak gazetesinde göbekte, Yeni Akit gazetesinde ise alt kuşakta yer almıştır. Farklı siyasi eksenlerde yer alan 5 gazetenin kadın milletvekili adayları ile ilgili haberleri yayınlarken birbirleriyle örtüşen konum seçimleri olmuştur. 3 gazete göbekte 2 gazete ise alt kuşakta en fazla habere yer vermiştir. Kadın adaylar ile ilgili haberlerin sayfadaki konumu bağlamında dikkat çekici konumlarda fazla sunulmadığı görülmektedir.

Tablo 4. Kadın milletvekili adayları ile ilgili haberlerin haber hiyerarşisi bağlamında birinci sayfadaki sıralaması

\begin{tabular}{|c|c|c|}
\hline $\begin{array}{c}\text { Haberin birinci sayfadaki } \\
\text { sıralaması }\end{array}$ & $\mathbf{f}$ & $\%$ \\
\hline 01 & 8 & 5,5 \\
\hline 02 & 2 & 1,4 \\
\hline 03 & 4 & 2,8 \\
\hline 04 & 7 & 4,8 \\
\hline 05 & 3 & 2,1 \\
\hline 06 & 3 & 2,1 \\
\hline 07 & 4 & 2,8 \\
\hline 08 & 1 & 0,7 \\
\hline 09 & 2 & 1,4 \\
\hline 10 ve üstü & 6 & 4,1 \\
\hline Haber birinci sayfada yer almıyor & 105 & 72,4 \\
\hline Toplam & 145 & 100,0 \\
\hline
\end{tabular}

Kadın milletvekili adayları ile ilgili haberlerin hiyerarşisi incelenirken haberler gazete sayfasının sol üst kısmından başlayarak numaralandırılmıştır. Burada okuyucunun sayfanın sol üst kısmından başlayarak gazeteyi okuduğu temel alınmaktadır. Kadın milletvekili adayları ile ilgili toplam 145 haberden 105 'inin birinci sayfada yer almadığı görülmektedir. Gazetenin en dikkat çeken ve en çok okunan kısımlarından olması dolayısıyla ve yahut birinci sayfada özet biçimde ele alınıp iç sayfadaki haberinde okunmasına dikkat çekilmesini sağlaması bağlamında haberlerin birinci sayfada yer alması büyük önem arz etmektedir. Haber hiyerarşisi bağlamında ise ilk sayfa haberlerinin 8'i $(\% 5,5)$ birinci sırada yer almaktadır. 
Tablo 5. Gazetelere göre kadın milletvekili adayları ile ilgili haberlerin sunum şekli

\begin{tabular}{|c|c|c|c|c|c|c|c|c|c|c|c|c|}
\hline \multirow{3}{*}{$\begin{array}{l}\text { Haberin } \\
\text { Sunum } \\
\text { Şekli }\end{array}$} & \multicolumn{10}{|c|}{ Gazeteler } & \multirow{2}{*}{\multicolumn{2}{|c|}{ Toplam }} \\
\hline & \multicolumn{2}{|c|}{ Birgün } & \multicolumn{2}{|c|}{ Cumhuriyet } & \multicolumn{2}{|c|}{ Posta } & \multicolumn{2}{|c|}{ Yeni Şafak } & \multicolumn{2}{|c|}{ Yeni Akit } & & \\
\hline & f & $\%$ & f & $\%$ & f & $\%$ & $f$ & $\%$ & $\mathbf{f}$ & $\%$ & $f$ & $\%$ \\
\hline Haber & 18 & 81,8 & 29 & 76,3 & 19 & 76,0 & 20 & 74,1 & 23 & 69,7 & 109 & 75,2 \\
\hline Başyazı & 0 & 0 & 0 & 0 & 0 & 0 & 0 & 0 & 0 & 0 & 0 & 0 \\
\hline Köşe Yazısı & 0 & 0 & 2 & 5,3 & 4 & 16,0 & 0 & 0 & 4 & 12,1 & 10 & 6,9 \\
\hline Röportaj & 3 & 13,6 & 0 & 0 & 1 & 4,0 & 1 & 3,7 & 1 & 3,0 & 6 & 4,1 \\
\hline $\begin{array}{l}\text { Haber- } \\
\text { Röportaj }\end{array}$ & 0 & 0 & 7 & 18,4 & 1 & 4,0 & 6 & 22,2 & 5 & 15,2 & 19 & 13,1 \\
\hline $\begin{array}{l}\text { Araştırma- } \\
\text { İnceleme }\end{array}$ & 1 & 4,5 & 0 & 0 & 0 & 0 & 0 & 0 & 0 & 0 & 1 & 0,7 \\
\hline Toplam & 22 & 100,0 & 38 & 100,0 & 25 & 100,0 & 27 & 100,0 & 33 & 100,0 & 145 & 100,0 \\
\hline
\end{tabular}

Gazetelere göre kadın milletvekili adayları ile ilgili haberlerin sunum şekli en fazla $\% 75,2$ 'lik oranı ile haber sunum şeklinde olmuştur. İncelenen gazetelerde başyazı sunum şekli hiç kullanılmamıştır. Toplamda 109 haber, 10 köşe yazısı, 6 röportaj, 19 haber-röportaj ve 1 araştırma-incelemeye yer verilmiştir. Haberler genel olarak seçime dair kaç adayın olduğu, isimlerin nerede aday gösterildiği gibi haberler olduğu için büyük oranı haber şeklinde sunulmuştur. Kadın milletvekili adayları ile ilgili haber yapılanması içerisinde adayların kendilerini ifade edebilecekleri röportaj ya da haberröportaj sunum şekillerinin kullanımı çok sınırlı düzeyde kalmıştır. Ayrıca gazetenin bir konudaki duruşunu ve düşüncesini yansıtan ve en değerli içerikler içerisinde yer alan başyazının hiçbir gazetede yer almaması da önemli bir eksiklik olarak değerlendirilebilir.

Tablo 6. Gazetelere göre kadın milletvekili adayları ile ilgili haberlerin düzenleme biçimi

\begin{tabular}{|c|c|c|c|c|c|c|c|c|c|c|c|c|}
\hline \multirow{3}{*}{$\begin{array}{l}\text { Haberin } \\
\text { Düzenlenme } \\
\text { Biçimi }\end{array}$} & \multicolumn{10}{|c|}{ Gazeteler } & \multirow{2}{*}{\multicolumn{2}{|c|}{ Toplam }} \\
\hline & \multicolumn{2}{|c|}{ Birgün } & \multicolumn{2}{|c|}{ Cumhuriyet } & \multicolumn{2}{|c|}{ Posta } & \multicolumn{2}{|c|}{$\begin{array}{l}\text { Yeni } \\
\text { Şafak }\end{array}$} & \multicolumn{2}{|c|}{ Yeni Akit } & & \\
\hline & $f$ & $\%$ & $f$ & $\%$ & $f$ & $\%$ & $f$ & $\%$ & $f$ & $\%$ & $f$ & $\%$ \\
\hline $\begin{array}{l}\text { Araştırma } \\
\text { Haber }\end{array}$ & 1 & 4,5 & 2 & 5,3 & 1 & 4,0 & 0 & 0 & 2 & 6,1 & 6 & 4,1 \\
\hline $\begin{array}{l}\text { Derleme } \\
\text { Haber }\end{array}$ & 0 & 0 & 0 & 0 & 0 & 0 & 0 & 0 & 0 & 0 & 0 & 0 \\
\hline $\begin{array}{l}\text { Tematik } \\
\text { Haber }\end{array}$ & 0 & 0 & 9 & 23,7 & 0 & 0 & 0 & 0 & 0 & 0 & 9 & 6,2 \\
\hline
\end{tabular}




\begin{tabular}{|l|c|c|c|c|c|c|c|c|c|c|c|c|}
\hline Bilgi Haber & 12 & 54,5 & 13 & 34,2 & 16 & 64,0 & 19 & 70,4 & 13 & 39,4 & 73 & 50,3 \\
\hline Olay Haber & 6 & 27,3 & 5 & 13,2 & 5 & 20,0 & 5 & 18,5 & 8 & 24,2 & 29 & 20,0 \\
\hline Öykü Haber & 3 & 13,6 & 4 & 10,5 & 0 & 0 & 1 & 3,7 & 3 & 6,1 & 10 & 6,9 \\
\hline Yorum & 0 & 0 & 5 & 13,2 & 3 & 12,0 & 2 & 7,4 & 8 & 24,2 & 18 & 12,4 \\
\hline Toplam & $\mathbf{2 2}$ & $\mathbf{1 0 0 , 0}$ & $\mathbf{3 8}$ & $\mathbf{1 0 0 , 0}$ & $\mathbf{2 5}$ & $\mathbf{1 0 0 , 0}$ & $\mathbf{2 7}$ & $\mathbf{1 0 0 , 0}$ & $\mathbf{3 3}$ & $\mathbf{1 0 0 , 0}$ & $\mathbf{1 4 5}$ & $\mathbf{1 0 0 , 0}$ \\
\hline
\end{tabular}

Haberin düzenleme biçimi, gazetelerin kadın adaylara bakış perspektifini yansıtması açısından ve haber kurgusunu belirlemesi açısından önem ifade etmektedir. Gazetelerde kadın milletvekili adayları ile ilgili haberlerin en çok kullanılan düzenlenme biçimi \%50,3 oranıyla bilgi haber olmuştur. Okurun seçimler ve adaylar hakkında bütünlüklü bir biçimde bilgilendirilmesini amaçlayan bu haberlerin tüm gazetelerde en yüksek oranda düzenlenme biçimi olduğu görülmektedir. İkinci sırada yer alan düzenleme biçimi ise olay haberler olmuştur. Seçim çalışmaları sırasında meydana gelen olay/olayların yer aldığı bu haber düzenleme biçimini en fazla kullanan gazete $\% 27,3$ ile Birgün gazetesi olmuştur. Öykü haber biçimine en fazla yer veren gazete kendi haberlerinin içerisinde \%13,6'sında bu biçimi kullanan Birgün gazetesi iken ki bu 3 habere karşılık gelmektedir. Yoruma en fazla yer veren gazete ise \%24,2 oranıyla Yeni Akit gazetesidir.

Tablo 7. Gazetelere göre kadın milletvekili adayları ile ilgili haberleri destekleyen görsel materyallerin kullanımı

\begin{tabular}{|c|c|c|c|c|c|c|c|c|c|c|c|c|}
\hline \multirow{3}{*}{$\begin{array}{l}\text { Haberi } \\
\text { Destekleyen } \\
\text { Görsel } \\
\text { Materyal }\end{array}$} & \multicolumn{10}{|c|}{ Gazeteler } & \multirow{2}{*}{\multicolumn{2}{|c|}{ Toplam }} \\
\hline & \multicolumn{2}{|c|}{ Birgün } & \multicolumn{2}{|c|}{ Cumhuriyet } & \multicolumn{2}{|c|}{ Posta } & \multicolumn{2}{|c|}{$\begin{array}{l}\text { Yeni } \\
\text { Şafak }\end{array}$} & \multicolumn{2}{|c|}{ Yeni Akit } & & \\
\hline & f & $\%$ & $f$ & $\%$ & $f$ & $\%$ & $f$ & $\%$ & $f$ & $\%$ & $f$ & $\%$ \\
\hline Fotoğraf & 19 & 86,4 & 27 & 71,1 & 20 & 80,0 & 26 & 96,3 & 23 & 69,7 & 115 & 79,3 \\
\hline Karikatür & 0 & 0 & 1 & 2,6 & 0 & 0 & 0 & 0 & 0 & 0 & 1 & 0,7 \\
\hline Grafik & 1 & 4,5 & 0 & 0 & 0 & 0 & 0 & 0 & 0 & 0 & 1 & 0,7 \\
\hline Yok & 2 & 9,1 & 10 & 26,3 & 5 & 20,0 & 1 & 3,7 & 10 & 30,3 & 28 & 19,3 \\
\hline Toplam & 22 & 100,0 & 38 & 100,0 & 25 & 100,0 & 27 & 100,0 & 33 & 100,0 & 145 & 100,0 \\
\hline
\end{tabular}

Habere verilen önemi veya taşıdığı mesajı en iyi yansıtacak unsurlardan biri görsel materyallerdir. Görsel materyallerin kullanımı habere dair ilk bakışta oluşturacağımız düşüncelere yön vermektedir. Haber içeriğinde yer alan ögelerin görseller aracılığı ile 
desteklenmesi ya da görsel olarak anlamlı bir bütün sunması önemlidir. Ayrıca görsel materyaller hem haberin kapladığı alanı hem de dikkat çekme oranını etkilemektedir.

Bu bağlamda kadın milletvekili adayları ile ilgili haberlerin 115'inde fotoğraf kullanılmış, 28'inde herhangi bir görsel materyale yer verilmemiştir. 1 haberde karikatür, 1 haberde ise grafik yer almıştır. Görsel materyaller içerisinde grafik unsurunun neredeyse hiç kullanılmaması okuyucuya sayısal verilerin aktarımında bir eksiklik olarak değerlendirilebilir. Çünkü kadın milletvekili aday sayısının niceliksel bağlamda düşük seviyede olması hedef kitleye en net grafikler ile yansıtılabilir.

Tablo 8. Kadın milletvekili adayları ile ilgili haberlerde yer alan aktörler

\begin{tabular}{|l|c|c|}
\hline \multicolumn{1}{|c|}{ Aktörler } & f & $\%$ \\
\hline Cumhurbaşkanı & 5 & 1,8 \\
\hline Başbakan & 6 & 2,2 \\
\hline İktidar Partisi Genel Başkanı & 7 & 2,6 \\
\hline Muhalefet Partisi Genel Başkanı & 12 & 4,4 \\
\hline Kadın Milletvekili Adayı & 145 & 52,9 \\
\hline Erkek Milletvekili Adayı & 43 & 15,7 \\
\hline Kadın Milletvekili Adayının Eşi & 11 & 4,0 \\
\hline Erkek Milletvekili Adayının Eşi & 0 & 0 \\
\hline STK Temsilcisi & 5 & 1,8 \\
\hline Erkek Milletvekili Adayının Yakını & 0 & 0 \\
\hline Kadın Milletvekili Adayının Yakını & 8,0 \\
\hline Muhalefet Partisinin İ Temsilcisi & 22 & 0,4 \\
\hline Muhalefet Partisinin İlçe Temsilcisi & 1 & 0,4 \\
\hline İktidar Partisinin Kadın Kolları Temsilcisi & 1 & 0,4 \\
\hline Muhalefet Partisinin Kadın Kolları Temsilcisi & 1 & 0,4 \\
\hline Diğer & 1 & 5,1 \\
\hline Toplam & $\mathbf{2 7 4}$ & $\mathbf{1 0 0 , 0}$ \\
\hline
\end{tabular}

Kadın milletvekili adayları ile ilgili toplam 145 haber gazetelerde yer almaktadır. Bu haberlerde 2745 aktör yer almış ve haberlerin 43 tanesi kadın adayların ve erkek adayların birlikte ele alındığı haberleri kapsamıştır. 22 haberde kadın milletvekili adayı yakını ile ele alınmış ayrıca 14 haberde listede yer almayan diğer aktörlere yer verilmiştir. Kadın adayların haberlerinde yoğunlukla farklı aktörlerin yer aldığı gözlemlenmektedir. Çalışmanın sayıltılarında ortaya koyulan 'Kadın milletvekili adayları ile ilgili haberlerde çoğunlukla farklı aktörler devreye girmektedir.' durumu ile de örtüşmektedir. Ayrıca 12 haberde muhalefet partisi genel başkanı, 11 haberde ise kadın milletvekili adayının eşi yer almaktadır. 145 haberde 274 farklı aktörün yer alıyor olması kadın milletvekili adaylarının tek başlarına ön planda sunulmadığını ortaya koymaktadır. Haberlerde adayların eş ve yakınları ile anılırken; erkek adayların tek başlarına bir siyasi figür 
olarak değerlendirilmesi dikkat çekicidir. Haberlerin \%12'sinde kadın milletvekili adayı ya eşi ya da yakını ile anılmıştır. Bu haberlerin önemli bir kısmında kadının haberin öznesi konumundan çıkartıldığı görülmektedir. Adayın eşinin, babasının ya da tanınmış yakın bir akrabasının ön plana çıkartıldığı dikkati çekmektedir. Dolayısıyla kadının siyaset sahnesinde de kendi kimliği, yeteneği ve birikimiyle var olabileceği göz ardı edilerek kadın dominant bir erkek figürünün yanına iliştirilmektedir.

Tablo 9. Gazetelere göre kadın milletvekili adayları ile ilgili haberlerin niteliği

\begin{tabular}{|c|c|c|c|c|c|c|c|c|c|c|c|c|}
\hline \multirow{3}{*}{$\begin{array}{c}\text { Haberin } \\
\text { Niteliği }\end{array}$} & \multicolumn{10}{|c|}{ Gazeteler } & \multirow{2}{*}{\multicolumn{2}{|c|}{ Toplam }} \\
\hline & \multicolumn{2}{|c|}{ Birgün } & \multicolumn{2}{|c|}{ Cumhuriyet } & \multicolumn{2}{|c|}{ Posta } & \multicolumn{2}{|c|}{$\begin{array}{l}\text { Yeni } \\
\text { Şafak }\end{array}$} & \multicolumn{2}{|c|}{ Yeni Akit } & & \\
\hline & $f$ & $\%$ & $f$ & $\%$ & $f$ & $\%$ & $f$ & $\%$ & $f$ & $\%$ & $f$ & $\%$ \\
\hline Açıklama & 8 & 36,4 & 12 & 31,6 & 3 & 12,0 & 10 & 37,0 & 8 & 24,2 & 41 & 28,3 \\
\hline İddia & 0 & 0 & 0 & 0 & 0 & 0 & 0 & 0 & 4 & 12,1 & 4 & 2,8 \\
\hline Eleştiri & 4 & 18,2 & 1 & 2,6 & 3 & 12,0 & 0 & 0 & 6 & 18,2 & 14 & 9,7 \\
\hline Beklenti & 0 & 0 & 4 & 10,5 & 0 & 0 & 0 & 0 & 0 & 0 & 4 & 2,8 \\
\hline $\begin{array}{l}\text { Ç ö z ü m } \\
\text { Ö n e r i s i } \\
\text { Getirme }\end{array}$ & 0 & 0 & 0 & 0 & 0 & 0 & 0 & 0 & 0 & 0 & 0 & 0 \\
\hline Destek & 0 & 0 & 0 & 0 & 0 & 0 & 0 & 0 & 1 & 3,0 & 1 & 0,7 \\
\hline Bilgilendirme & 10 & 45,5 & 21 & 55,3 & 19 & 76,0 & 17 & 63,0 & 14 & 42,4 & 81 & 55,9 \\
\hline Toplam & 22 & 100,0 & 38 & 100,0 & 25 & 100,0 & 27 & 100,0 & 33 & 100,0 & 145 & 100,0 \\
\hline
\end{tabular}

Gazetelere göre kadın milletvekili adayları ile ilgili haberlerin niteliği \%55,9 oranında bilgilendirme şeklindedir. İkinci sırada ise \%28,3 oranı ile açıklama niteliğindeki haberler gelmektedir. Çözüm önerisi getirme niteliğindeki haberler hiçbir gazetede yer bulamamıştır. Milletvekili adaylığına dair seçim sürecinde siyasi konuların daha fazla ele alınması bağlamında cinsiyet eşitliğine dair haberlerin çözüm odaklı bir nitelikte daha fazla yer alması anlamlı olacak iken incelenen tüm gazetelerde bu inmal edilmiştir. Üçüncü sırada gelen eleştiri niteliğindeki haberler $(\% 9,7)$ ise siyasi atışmaların yaşandığı olayların seçim sürecine dahil bir biçimde sunulması anlamına gelmektedir. Siyasi atışmaların ötesinde birçok kadın adaya getirilen yerli yersiz eleştiriler gazetelerde yer almış ve eleştiri haber niteliğinde okuyucuya sunulmuştur. Bilgilendirme bölümünün yer aldığı bu haberlerde kadın aday ile ilgili bilgiler verilirken diğer taraftan eleştirel tutumlar habere dahil edilerek süreç dışında işleyen gündemler haberlere dahil edilmiştir. 
Tablo 10. Kadın milletvekili adayları ile ilgili haberlerin temel konuları

\begin{tabular}{|l|c|c|}
\hline \multicolumn{1}{|c|}{ Temel Konular } & $\mathbf{f}$ & $\%$ \\
\hline Seçim Çalışması & 37 & 17,9 \\
\hline Siyaset ve Kadın & 69 & 33,3 \\
\hline Seçim Vaatleri ve Söylemi & 27 & 13,0 \\
\hline Siyasal Magazin & 65 & 31,4 \\
\hline Diğer & 9 & 4,3 \\
\hline Toplam & $\mathbf{2 0 7}$ & $\mathbf{1 0 0 , 0}$ \\
\hline
\end{tabular}

Not: Bazı haberlerde birden fazla konu yer almaktadır. Bu nedenle genel toplam 207'dir.

Kadın milletvekili adayları ile ilgili haberlerin temel konularından en büyük paya sahip olan konu \%33,3 oranıyla siyaset ve kadın konusudur. Hemen ardından \%31,4 oranı ile siyasal magazin gelmektedir. Haberlerin büyük bir bölümün siyasal magazin konusuna dahil edilerek ele alınması medyada yaşanan siyaset ilişkilerini ortaya koymaktadır. Kadın adaylarla ilgili haberlerin çoğunluğundan adaya dair rutin bilgiler yer aldıktan sonra siyasal magazin başlıklarında inceleyeceğimiz söylem tarzına yer verilmiştir. Siyasal magazin içerisinde kadın milletvekili adayının aile yaşamı, fiziksel özellikleri, yaşı, giyimi, yakın çevresindeki tanınmış kişiler ele alınmaktadır. Bu başlıklar ışığında kadın adaylar tanıtıırken magazinel bir dilin kullanıldığı açıkça ortaya konulmaktadır.

\subsection{Erkek Milletvekili Adayları İe İlgili Haberlere İlișkin Haberlerin İçerik Çözümlemesi}

Çalışmada kadın milletvekili adayları ve erkek milletvekili adayları ile ilgili haberlerin karşılaştırılabilmesi için erkek milletvekili adaylarını içeren haberler de belirli kategorilerde incelenmiştir.

Tablo 11. Gazetelere göre erkek milletvekili adayları ile ilgili haber dağılımları

\begin{tabular}{|l|c|c|}
\hline Gazete İsimleri & $\mathbf{f}$ & $\%$ \\
\hline Birgün & 68 & 20,9 \\
\hline Cumhuriyet & 84 & 25,8 \\
\hline Posta & 57 & 17,5 \\
\hline Yeni Şafak & 47 & 14,5 \\
\hline Yeni Akit & 69 & 21,2 \\
\hline Toplam & $\mathbf{3 2 5}$ & $\mathbf{1 0 0 , 0}$ \\
\hline
\end{tabular}

Araştırmanın bu bölümünde erkek milletvekili adayları ile ilgili olan haberler dar kapsamlı bir içerik analizi ile incelenmiştir. İncelenen gazetelerde erkek milletvekili adayları ile ilgili en çok haber Cumhuriyet gazetesinde (84 haber) yer almıştır. Bu noktada kadın milletvekili adayları ile ilgili en fazla haberin yine aynı gazetede yer aldığı görülmektedir. İkinci en fazla habere yer veren gazete kadın milletvekili 
adaylarında olduğu gibi yine Yeni Akit gazetesi (69 haber) olmuştur. 68 haber ile onu takip eden gazete Birgün gazetesidir. Ardından 57 haber ile Posta, 47 haber ile Yeni Şafak gazeteleri gelmektedir.

Tablo 12. Erkek milletvekili adayları ile ilgili haberlerin yer aldığı sayfalar

\begin{tabular}{|l|c|c|}
\hline Haberin sayfası & $\mathrm{f}$ & $\%$ \\
\hline Birinci sayfa & 14 & 4,3 \\
\hline $\begin{array}{l}\text { Birinci sayfada başlayıp iç } \\
\text { sayfada devam eden }\end{array}$ & 57 & 17,5 \\
\hline İç sayfa & 254 & 78,2 \\
\hline Toplam & $\mathbf{3 2 5}$ & $\mathbf{1 0 0 , 0}$ \\
\hline
\end{tabular}

Bulgular çerçevesinde kadın milletvekili adayları ve erkek milletvekili adayları ile ilgili haberler belirli sınırlar çerçevesinde karşılaştırılmıştır. Tablo 12'de yer verilen bulgulara göre incelenen 200 gazete sayısında 325 erkek milletvekili adayı ile ilgili haber yer almıştır. Birinci sayfada yer alan ve birinci sayfada başlayan haberlerin toplamı \%21,8 oranında kalmıştır. Haberlerin \%78,2'lik kısmı iç sayfada bulunmaktadır. Tablo 2'deki verilerle karşılaştırdığımızda kadın adaylar ile ilgili haberlerin daha fazla birinci sayfada $(\% 27,6)$ yer aldığı görülmektedir. Bu noktada kadın adaylar ile ilgili haberler 145 ve erkek adaylar ile ilgili 325 haber vardır ancak kadın adaylar gazetelerde daha az yer almalarına rağmen birinci sayfalarda daha fazla yer alması bir kazanım olarak nitelendirilebilir.

Tablo 13. Erkek milletvekili adayları ile ilgili haberlerin sayfadaki konumu

\begin{tabular}{|l|c|c|}
\hline Haberin sayfadaki konumu & $\mathrm{f}$ & $\%$ \\
\hline Sürmanşet & 5 & 1,5 \\
\hline Manşet & 16 & 4,9 \\
\hline Üst Kuşak & 66 & 20,3 \\
\hline Göbek & 122 & 37,5 \\
\hline Alt Kuşak & 112 & 34,5 \\
\hline Tam Sayfa & 4 & 1,2 \\
\hline Toplam & $\mathbf{3 2 5}$ & $\mathbf{1 0 0 , 0}$ \\
\hline
\end{tabular}

Erkek milletvekili adayları ile ilgili haberler kadın adaylarda olduğu gibi en fazla göbekte yer almışlardır. Göbeği takiben alt kuşak ve üst kuşak gelmiştir. Kadın milletvekili adayları ile ilgili haberlerin sayfadaki konumu Tablo 3'te verilmiştir. Erkek adaylar ile kadın adayların haberlerinin sayfadaki konumları seçilirken gazetelerin benzer eğilimler gösterdiği görülmektedir. Kadın milletvekili adayları ile ilgili haberler de en çok göbekte yer almış, ikinci sırada alt kuşak, üçüncü sırada ise üst kuşakta yer almışlardır. Seçim listelerinin sunulmasının ardından haberlerin kadın ve erkek milletvekili adaylarını aynı haberler içerisinde sunduğu dikkate alındığında bu bulgular anlamlandırılmaktadır. 
Tablo 14. Erkek milletvekili adayları ile ilgili haberlerin haber hiyerarşisi bağlamında birinci sayfadaki sıralaması

\begin{tabular}{|c|c|c|}
\hline $\begin{array}{l}\text { Haberin birinci sayfadaki } \\
\text { sıralaması }\end{array}$ & $\mathbf{f}$ & $\%$ \\
\hline 01 & 6 & 1,8 \\
\hline 02 & 6 & 1,8 \\
\hline 03 & 9 & 2,8 \\
\hline 04 & 12 & 3,7 \\
\hline 05 & 7 & 2,2 \\
\hline 06 & 9 & 2,8 \\
\hline 07 & 5 & 1,5 \\
\hline 08 & 5 & 1,5 \\
\hline 09 & 3 & 0,9 \\
\hline 10 ve üstü & 8 & 2,5 \\
\hline Haber birinci sayfada yer & 255 & 78,5 \\
\hline almır & 325 & 100,0 \\
\hline Toplam & & \\
\hline
\end{tabular}

Erkek milletvekili adayları ile ilgili haberlerin \%3,2'lik bir bölümü haber hiyerarşisi bağlamında birinci sayfada en fazla 4.sırada bulunmaktadır. Kadın adaylar ile ilgili haberler en fazla 1. sırada yer almaktadır. Burada kadın ve erkek adaylar ile ilgili haberlerin hiyerarşik sıralamada eşit sunulmadığı gözlenmektedir. Kadın milletvekili ile ilgili haberler gazetelerde daha fazla üst sıralar ya da alt sıralarda yer almıştır.

Tablo 15. Erkek milletvekili adayları ile ilgili haberlerin haber hiyerarşisi bağlamında iç sayfadaki sıralaması

\begin{tabular}{|c|c|c|c|c|c|c|c|c|c|c|c|c|}
\hline \multirow{3}{*}{$\begin{array}{c}\text { Haberin } \\
\text { İç } \\
\text { Sayfadaki } \\
\text { Sıralaması }\end{array}$} & \multicolumn{10}{|c|}{ Gazeteler } & \multirow{2}{*}{\multicolumn{2}{|c|}{ Toplam }} \\
\hline & \multicolumn{2}{|c|}{ Birgün } & \multicolumn{2}{|c|}{ Cumhuriyet } & \multicolumn{2}{|c|}{ Posta } & \multicolumn{2}{|c|}{ Yeni Şafak } & \multicolumn{2}{|c|}{ Yeni Akit } & & \\
\hline & $f$ & $\%$ & $f$ & $\%$ & $f$ & $\%$ & $f$ & $\%$ & $f$ & $\%$ & f & $\%$ \\
\hline 01 & 6 & 8,8 & 12 & 14,3 & 9 & 15,8 & 3 & 6,4 & 7 & 10,1 & 37 & 11,4 \\
\hline 02 & 6 & 8,8 & 10 & 11,9 & 2 & 3,5 & 7 & 14,9 & 10 & 14,5 & 35 & 10,8 \\
\hline 03 & 8 & 11,8 & 13 & 15,5 & 4 & 7,0 & 7 & 14,9 & 12 & 17,4 & 44 & 13,5 \\
\hline 04 & 4 & 5,9 & 10 & 11,9 & 1 & 1,8 & 5 & 10,6 & 6 & 8,7 & 26 & 8,0 \\
\hline 05 & 3 & 4,4 & 9 & 10,7 & 2 & 3,5 & 7 & 14,9 & 9 & 13,0 & 30 & 9,2 \\
\hline 06 & 11 & 16,2 & 6 & 7,1 & 3 & 5,3 & 5 & 10,6 & 7 & 10,1 & 32 & 9,8 \\
\hline 07 & 1 & 1,5 & 4 & 4,8 & 3 & 5,3 & 1 & 2,1 & 4 & 5,8 & 13 & 4,0 \\
\hline 08 & 1 & 1,5 & 2 & 2,4 & 8 & 14,0 & 1 & 2,1 & 2 & 2,9 & 14 & 4,3 \\
\hline
\end{tabular}




\begin{tabular}{|c|c|c|c|c|c|c|c|c|c|c|c|c|}
\hline 09 & 1 & 1,5 & 0 & 0 & 6 & 10,5 & 0 & 0 & 2 & 2,9 & 9 & 2,8 \\
\hline 10 ve üstü & 2 & 2,9 & 1 & 1,2 & 9 & 15,8 & 1 & 2,1 & 2 & 2,9 & 15 & 4,6 \\
\hline $\begin{array}{c}\text { Haber iç } \\
\text { sayfada } \\
\text { yer } \\
\text { almıyor }\end{array}$ & 3 & 4,4 & 2 & 2,4 & 5 & 8,8 & 2 & 4,3 & 1 & 1,4 & 13 & 4,0 \\
\hline $\begin{array}{c}\text { Birinci } \\
\text { sayfada } \\
\text { başlayıp } \\
\text { iç sayfa } \\
\text { devam } \\
\text { eden } \\
\text { haber }\end{array}$ & 22 & 32,4 & 15 & 17,9 & 5 & 8,8 & 8 & 17,0 & 7 & 10,1 & 57 & 17,5 \\
\hline \begin{tabular}{c} 
Toplam \\
\hline
\end{tabular} & 68 & 100,0 & 84 & 100,0 & 57 & 100,0 & 47 & 100,0 & 69 & 100,0 & 325 & 100,0 \\
\hline
\end{tabular}

Erkek milletvekili adayları ile ilgili haberlerinin iç sayfadaki konumu \%13,5 ile en fazla 3 numaralı sıralamada yer almıştır. Takiben 1 numaralı sıralamayı en çok kullanan gazetelerin sıralaması Posta $(\% 15,8)$, Cumhuriyet $(\% 14,3)$, Yeni Akit, Birgün $(\% 8,8)$ ve Yeni Şafak $(\% 6,4)$ şeklinde olmuştur. Kadın milletvekili adayların bu sıralama Cumhuriyet, Yeni Akit, Birgün, Posta ve Yeni Şafak biçiminde gerçekleşmiştir. Erkek milletvekili adayları ile ilgili haberler en fazla 3 numaralı sıralamada yer almışlardır. 10 ve üstü sıralamasını en çok kullanan gazete ise \%15,8 oranı ile Posta gazetesi olmuştur.

\section{Sonuç}

Bu çalışmada 7 Haziran 2015 Genel Seçimi ve 1 Kasım 2015 Genel Seçimi için milletvekili aday listelerinin kesinleşmiş olduğu tarihten itibaren kadın milletvekili adaylarının yazılı basında yer alışı içerik analizi ile incelenmiştir. İçerik analizi yönteminde kadın milletvekili adayları ve erkek milletvekili adayları ile ilgili haberleri karşılaştırabilmek için erkek milletvekili adayları ile ilgili haberler incelemeye dahil edilmiştir. Her iki seçim döneminden, örneklemi oluşturan gazetelerden toplam 40 gün boyunca basılan 200 gazete; içerik analizi ile incelenmiştir. Kadın milletvekili adayları farklı gazetelerde benzer biçimlerde ayrımcılığa uğramış, siyasal alanın eril niteliklere sahip olduğu kabulünden hareketle kadın oranının yüksek olduğu iddiası her gazetede dikkat çekici bir biçimde yer almıştır. Kadın adaylar toplumdaki bir azınlıkmış gibi görülerek ülkenin yarısının kadınlar olduğu unutulmuş ve sayıların artması anormal bir durum gibi değerlendirilerek yansıtılmıştır. Erkeğin siyasette bulunduğu konum normalleştirilerek, kadın ötekileştirilmiştir. Bu bağlamda ataerkil söylemler çekincesiz bir biçimde ortaya konulmuştur.

Erkek milletvekili adayları ile ilgili haberler gazetelerde daha fazla yer almıştır. Erkek milletvekili adayları ile ilgili 325 haber, kadın milletvekili adayları 145 haber sunulmuştur. Erkek milletvekili adayı ile ilgili haberler \%21,8 oranında, kadın milletvekili adayı 
ile ilgili yapılan haberler ise \%27,6 oranında birinci sayfada yer almıştır. Buna göre erkek milletvekili adayları ile ilgili haberler daha az birinci sayfada yer almaktadır. Erkek milletvekili adayları ile ilgili haberlerin \%3,2'lik bir bölümü haber hiyerarşisi bağlamında birinci sayfada en fazla 4 numaralı sırada bulunmaktadır. Kadın adaylar ile ilgili haberler birinci sayfada en fazla 1 numaralı sıralamada yer almaktadır. Burada kadın ve erkek adaylar ile ilgili haberlerin hiyerarşik sıralamada eşit sunulmadığı gözlenmektedir. Kadın milletvekili ile ilgili haberler gazetelerde daha fazla üst sıralar ya da alt sıralarda bulunmaktadır. Bu noktada erkek milletvekili adayı ile ilgili haberler kadın milletvekili adayı ile ilgili yapılan haberlere göre haber hiyerarşisi bağlamında birinci sayfada daha alt sıralamada yer almaktadır. Erkek milletvekili adayları ile ilgili haberlerin \%13,5 haber hiyerarşisi bağlamında iç sayfada en fazla 3 numaralı sıralamada bulunmaktadır. Kadın milletvekili ile ilgili haberler ise iç sayfada \%15,2 oranı ile 1 numaralı sıralama olmuştur. Kadın milletvekili adayları ile ilgili haberlerde magazinleştirme ve haber değeri bağlamında ilginçlik öğesi daha fazla ön plana çıktığı için bu haberler üst sıralarda yer almıştır.

Erkek adaylar ile kadın adayların haberlerinin sayfadaki konumları seçilirken gazeteler benzer eğilimler göstermiştir. Kadın milletvekili adayları ile ilgili haberler en çok göbekte yer almış, ikinci sırada alt kuşak, üçüncü sırada ise üst kuşakta yer almışlardır. Aynı şekilde erkek milletvekili adaylarının haberleri konumlandırılmıştır. Buradan hareketle incelenen gazetelerin genelinde kadın milletvekili adayı ile ilgili haberlerin sayfadaki konumu erkek milletvekili ile ilgili haberlere göre daha az dikkat çeken bir konuma sahiptir denilememektedir.

Kadın milletvekili adayı ile ilgili haberlerde çoğunlukla farklı aktörlerin devreye girdiği bulgular arasındadır. Kadın adaylar ile ilgili haberlerin aktör sayısı bulanan haber sayısının neredeyse iki katına denk gelmektedir. Kadın adaylar sıklıkla parti başkanları, erkek milletvekili adayı ya da eşleri/yakın akrabaları ile ele alınmıştır. Ayrıca kadın milletvekili adayları ile ilgili haberlerin \%31,4'lük bir bölümü magazinel iletilerle sunulmuştur. Haberlerin büyük bir oranında ise fotoğraf kullanılmıştır.

Bu bulgulara göre:

- Yazılı basının kadın odaklı haber anlayışı geliştirmeleri ve kadın bakış açısına sahip haberler ortaya koyabilmeleri gerekmektedir.

- Toplumsal normların yeniden üretilmesi ve inşası sürecinde büyük bir öneme sahip olan medya, toplumsal cinsiyet eşitsizliklerini pekiştirdiğinin ve yeniden ürettiğinin farkına vararak bunları engelleyici önlemler almalıdır.

- Kadınların en az temsile sahip olduğu siyasal alanda, temsile ve eşitliğe duyarlı olunması ve bunun haberlere yansıtılması okur kitlesinin de ötekileştirici bakış açısını değiştirmesi açısından büyük öneme sahiptir.

- Gazetelerin en etkin ve değerli içeriklerinden biri olan "başyazı" kadının siyasetteki yerini daha iyi noktalara taşımak için mutlaka kullanılmalıdır.

- Siyaset ve kadına dair haberler magazinel bir sunumdan uzak olmalıdır.

- Kadınlara dair ele alınacak haberlerde öncelik kadınlara ait olmalı farklı aktörler eğer gerekiyorsa haberde kadınların önüne geçmeyecek şekilde sunulmalıdır. 
- Haberlerde yer alan farklı aktörler (özellikle eş, baba vd.) kadınları tanımlamak ve kadının siyasette var olma nedeni biçiminde verilmemelidir.

- Araştırma, derleme ve tematik haber düzenleme biçimlerine daha fazla yer verilmelidir. Özellikle araştırma haber ile Türkiye'de ve Dünya' da kadının siyasetteki yeri bilimsel raporlar ve istatistiksel sonuçlar bağlamında verilmelidir. - Röportaj, kadın milletvekili adaylarının kendi bakış açılarından kamuoyuna tanıtıldığı, beklenti ve sorunlarının ilk elden verildiği sunum şeklidir. Kadın milletvekillerine kendilerini kamuoyuna daha iyi anlatabilmeleri için gazetelerde röportaj sunum şeklinin daha fazla yer alması gerekmektedir.

- Kadının siyasetteki yerine bütünlüklü bir perspektiften bakan "çözüm önerisi getirme" niteliğindeki haberlere toplumsal bir tartışma platformu yaratabilmek için kesinlikle yer verilmelidir. Böylelikle kamuoyunun bilinçlenmesi sağlanmalıdır.

- Kadın odaklı habercilik anlayışı geliştirilmeli, eşitlik ilkesi basında yer almalıdır.

- Alternatif medya söylemleri örnek alınmalıdır.

- Medyada tekelleşme ile ortaya çıkan ortak/benzer söylem kısırlığı, bağımsız ve alternatif örgütlenme örnekleri ile aşılmalıdır.

Bu çalışmada, kadın milletvekili adaylarının yazılı basında temsil ediliş biçimleri toplumsal cinsiyet eşitsizlikleri temelinde incelenmiştir. Sonuç olarak, kadının siyasette de ötekileştirildiği ve erkek egemenliğinin medya içeriklerine hâkim olduğu görülmektedir. Kadın siyasi aktörlerin; farklı medya içeriklerindeki (televizyon, radyo, dergi ve yeni medya içerikleri) temsil edilme biçimlerinin araştırmacılar tarafından benzer yöntemlerle irdelenmesi sorunsalın çözümüne olumlu ivmeler katacaktır.

\section{Kaynakça}

Aaltio- Marjosola, I. \& Kovalainen, A. (2001). Personality. E. Wilson (Edt.), Organizational Behaviour Reassessed (s. 17-36). London: Sage Publications.

Acar- Savran, G. (2004). Beden, Emek, Tarih. İstanbul: Pusula Yayıncılık.

Acar-Savran, G. \& Demiryontan, N.T. (2008). Kadının Görünmeyen Emeği. İstanbul: Yordam Kitap

Aktaş, G. (2013). Feminist Söylemler Bağlamında Kadın Kimliği: Erkek Egemen Bir Toplumda Kadın Olmak. Edebiyat Fakültesi Dergisi, 30 (1), 53-72.

Arat, N. (1997). Susmayan Yazılar. İstanbul: Say Yayınları

Arsan, E., Ünalan, E., \& Türkoğlu, S. (2009). Cinsiyetçilik ve Medya: ‘Güzin Abla' Köşesinde Yeniden Üretilen Ataerkil Cins Kimlikleri. Cogito, Feminizm, 58, 385-402.

Aslan, Ö., \& Gambetti, Z. (2009). Fraser ve Feminizm: Söylem Kimin Söylemi, Tarih Kimin Tarihi? Kültür ve Siyasette Feminist Yaklaşımlar, 9, 1-16.

Bensadon, N. (1990). Başlangııından Günümüze Kadın Hakları (Çev. Ş. Tekeli). İstanbul: İletişim Yayınları.

Berktay, F. (2012). Tarihin Cinsiyeti (4. bs.). İstanbul: Metis Yayıncılık. 
Connell, R.W. (1998). Toplumsal Cinsiyet Ve Iktidar, Toplum, Kişi ve Cinsel Politika (Çev. C. Soydemir). İstanbul: Ayrıntı Yayınevi.

Coştu, Y. (2009). Toplumsallaşma Kavramı Üzerine Sosyolojik Bir Değerlendirme. Din Bilimleri Journal, 9 (3), 117-140.

Çardak, M. (2012). Toplumsal Bir Hareket Ve Aydınlanmanın Ürünü Olarak Liberal Feminizm. Yayımlanmamış yüksek lisans tezi, Gazi Üniversitesi, Ankara.

Dedeoğlu, S. (2000). Toplumsal Cinsiyet Rolleri Açısından Türkiye'de Aile ve Kadın Emeği. Toplum ve Bilim, 86, 139-170.

Doğan, C. (2008). Yeni Sosyal Hareketler Ekseninde Feminizme Bakış. Sosyoloji Notları, 4-5, 29-35.

Donovan, J. (2014). Feminist Teori (Çev. A. Bora, M. A. Gevrek ve F. Sayılan). İstanbul: Iletişim Yayıncılık.

Ecevit, Y. (2003). Toplumsal Cinsiyetle Yoksulluk Ilişkisi Nasıl Kurulabilir? Bu Ilişki Nasıl Çalışabilir? Cumhuriyet Üniversitesi Tıp Fakültesi Dergisi, 2003 Özel Eki, 25(4), 83-88.

Ecevit, Y. (2011). Kentsel Üretim Sürecinde Kadın Emeğinin Konumu ve Değişen Biçimleri. Ş. Tekeli (Yayına Hazırlayan), 1980'ler Türkiyesi'nde Kadın Bakış Açısından Kadınlar, içinde (s. 161178). İstanbul: İletişim.

Engels, F. (2012). Ailenin Özel Mülkiyetin ve Devletin Kökeni (Çev. K. Somer). Ankara: Sol Yayınları.

Esen, A.T. ve Memişoğlu, O. (2007). Siyasetin Cinsiyeti. 28 Mayıs 2015 tarihinde http://www. tepav.org.tr/upload/files/1271250684r7712.Siyasetin_Cinsiyeti.pdf adresinden alınmıştır.

Fidan, F. (2000). Kapitalizmin Gelişme Sürecinde Kadının Çok Yönlü Konumu (Medya Örneği). Bilgi, 2, 117-133.

Gökçimen, S. (2008). Ülkemizde Kadınların Siyasal Hayata Katıım Mücadelesi. Yasama Dergisi, 10, 5-59.

Gül, S.S. (2007). 22 Temmuz Seçiminin Galibi Kim? Bıyıklı Kadınlar mı Yoksa Eril Siyaset mi?. Toplum ve Demokrasi Dergisi, 1(1), 1-26.

Güngör, Ö. (2013). Sosyolojik Bir Teori Olarak Sembolik Etkileşimciliğin Ontolojik Temeli ve Din Olgusu. Abant İzzet Baysal Üniversitesi Sosyal Bilimler Enstitüsü Dergisi, Bahar 2013, 13(1), 57

Kaylı, D.Ş. (2014). Türkiye'de Yazılı Basında Parlamentodaki Siyasi Partilerin Kadın Politikalarındaki Temsili: 2011 Genel Seçimleri Üzerine Bir İnceleme. Journal of Yasar University, 9(36), 6261-6380.

Köse, A. (2011). Türk Basınında Kadın: 2010 Türkiye'sinde Sosyal Haklar Açısından Kadınların Temsili. Sosyal Haklar Uluslararası Sempozyumu.

Mitchell, J. (2006). Kadınlar: En Uzun Devrim. (Çev. G. İnal, G. Savran, Ş. Tekeli, F. Tınç, Ş. Torun ve Y. Zihnioğlu). İstanbul: Agora.

Nicolson, P. (2005). Gender, Power And Organisation. New York: Routledge. 
O'shaughnessy, M., \& Stadler, J. (2012). Media and Society. Oxford University Press.

Örnek, S. (2015). ABD'de Kadın Haklarının Gelişimi. Kocaeli Üniversitesi Sosyal Bilimler Enstitüsü Dergisi, 29, $105-129$.

Özalp, H. (ty.). Toplumsal Cinsiyet ve Siyaset Ilişkileri (Kadınların Siyasette Aday Olması ve Seçilmesinin Önündeki Engeller ve Çözüm Önerileri). Yayımlanmamış yüksek lisans tezi. İstanbul Gelişim Üniversitesi, İstanbul.

Özdamar, H. (2009). Laik-Antilaik Ekseninde Kadının Siyasallaşmasının Türk Yazıı Basınındaki Temsili. Yayımlanmamış yüksek lisans tezi. Ege Üniversitesi, İzmir.

Özdemir, G. (2009). Popüler Kadın Dergilerinde Toplumsal Cinsiyet Ayrımının Temsili: Cosmopolitan ve Bizim Aile Dergileri. Yayımlanmamış yüksek lisans tezi. Ege Üniversitesi, İzmir.

Özlük, E. (2007). Feminist Yaklaşım. H. Çakmak (Edt.), Uluslararası ilişkiler "Giriş, Kavram ve Teoriler" içinde (s.198-204). Ankara: Platin Yayınları.

Saktanber, A. (1980). Türkiye'de Medyada Kadın: Serbest, Müsait Kadın Veya İyi Eş, Fedakar. Ş. Tekeli (Yayına Hazırlayan), 1980'ler Türkiye'sinde Kadın Bakış Açısından Kadınlar içinde (ss.187206). İstanbul: İletişim.

Sankır, H. (2010). Toplumsal Cinsiyet Rollerinin Anlamlandırılış Biçiminin 'Kadın Sanatçı Kimliği'nin Oluşum Sürecine Etkileri. Hacettepe Üniversitesi Sosyolojik Araştırmalar e-dergisi. 9 Mayıs 2017 tarihinde http://www.sdergi.hacettepe.edu.tr/makaleler/hasan_sankir_1_1010.pdf adresinden alınmıştır.

Scott, J.W. (2007). Toplumsal Cinsiyet: Faydalı Bir Tarihsel Analiz Kategorisi (Çev. A. T. Kılıç). İstanbul: Agora Kitaplığı.

Taş, G. (2016). Feminizm Üzerine Genel Bir Değerlendirme: Kavramsal Analizi, Tarihsel Süreçleri ve Dönüşümleri. Akademik Hassasiyetler The Academic Elegance 3(5), 163-175.

Toplumsal Cinsiyet Sosyolojisi (Ty.) 6 Mayıs 2017 tarihinde https://sosyoloji7.wordpress.com /2012/10/29/toplumsal-cinsiyet-sosyolojisi adresinden alınmıştır.

Yıldırım, E. (2008). Modern Batı Uygarlığında Çatışmacı Teoriyi Besleyen Söylemler. Z. Dilek, M. Akbulut, E. Kâhya, Z. Bağlan Özer, R. Gürses, B. Karababa Taşkın (Edt.), Felsefe içinde(s. 435-447). 38. ICANAS (Uluslararası Asya ve Kuzey Afrika Çalışmaları Kongresi), Atatürk Kültür, Dil ve Tarih Yüksek Kurumu. 